\title{
The Evolution of FinTech:
}

\section{A New Post-Crisis Paradigm?}

\author{
Douglas W. Arner* \\ Jànos Barberis ${ }^{* *}$ \\ Ross P. Buckley ${ }^{* * *}$
}

\begin{abstract}
:
"Financial technology" or "FinTech" refers to technology enabled financial solutions. FinTech is often seen today as the new marriage of financial services and information technology. However, the interlinkage of finance and technology has a long history and has evolved over three distinct eras. FinTech 1.0, from 1866 to 1987, was the first period of financial globalization supported by technological infrastructure such as transatlantic transmission cables. This was followed by FinTech 2.0, from 1987-2008, during which financial services firms increasingly digitized their processes. Since 2008 a new era of FinTech has emerged in both the developed and developing world. This era is defined not by the financial products or services delivered but by who delivers them. This latest evolution of FinTech, led by start-ups, poses challenges for regulators and market participants alike, particularly in balancing the potential benefits of innovation with the possible risks of new approaches.
\end{abstract}

\footnotetext{
* Professor, Co-Director, Duke-HKU Asia America Institute in Transnational Law, and Member, Board of Management, Asian Institute of International Financial Law, Faculty of Law, University of Hong Kong.

**: Senior Research Fellow, Asian Institute of International Financial Law, Faculty of Law, University of Hong Kong; and Founder, FinTech HK.

*** CIFR King \& Wood Mallesons Chair of International Financial Law, Scientia Professor, and Member, Centre for Law, Markets \& Regulation, UNSW Australia.

The authors gratefully acknowledge the financial support of the the Hong Kong Research Grants Council Theme-based Research Scheme (Enhancing Hong Kong's Future as a Leading International Financial Centre) and the Australian Research Council Linkage Grant Scheme (Regulating a Revolution: A New Regulatory Model for Digital Finance).
} 


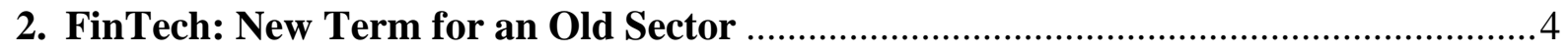

2.1 FinTech 1.0 (1866-1987): From Analogue to Digital ................................................................ 6

2.1.1 The first age of financial globalization ..............................................................

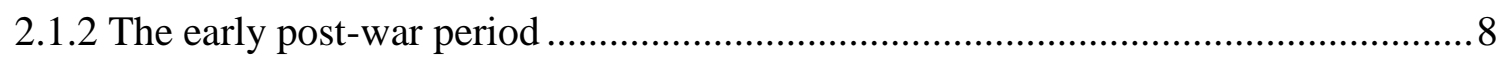

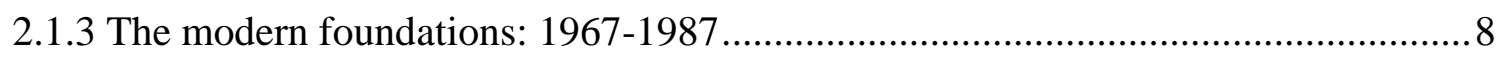

3. FinTech 2.0 (1987-2008): Development of Traditional Digital Financial Services ...... 10

3.1 Regulatory approaches to traditional DFS in FinTech 2.0 ....................................................... 12

4. FinTech 3.0 (2009 - present): Democratizing Digital Financial Services? ................. 15

4.1 FinTech and the Global Financial Crisis: Evolution or Revolution? ......................................... 15

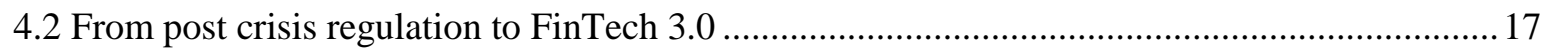

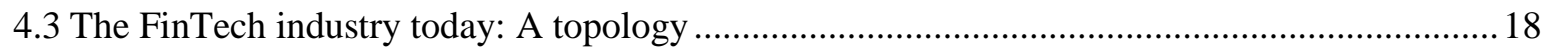

5. FinTech 3.5 in Emerging Markets: The Examples of Asia and Africa ........................20

5.1 FinTech opportunities and limitations in the Asia-Pacific Region ........................................... 21

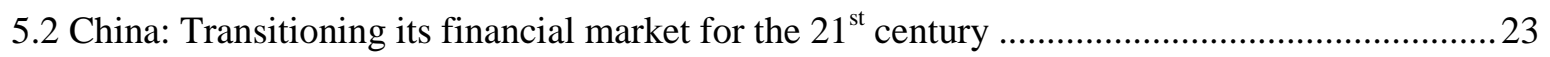

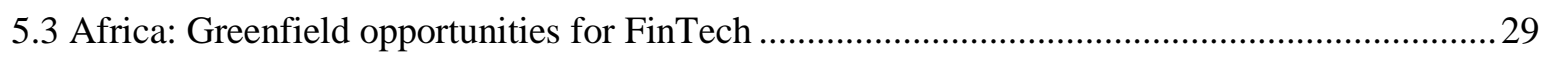

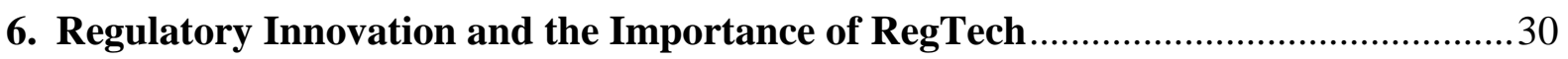

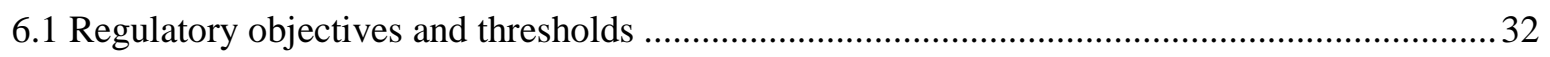

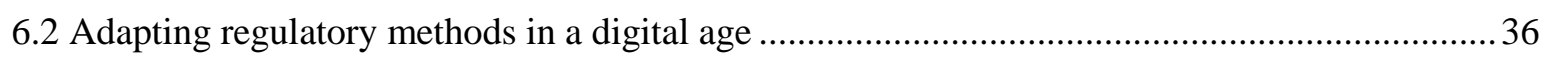

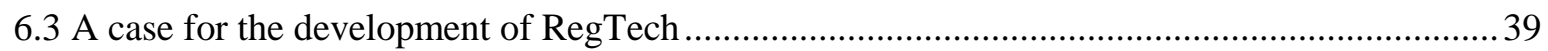

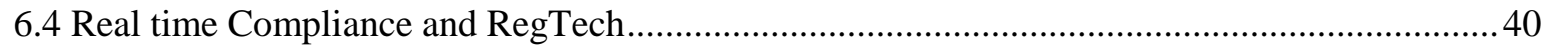

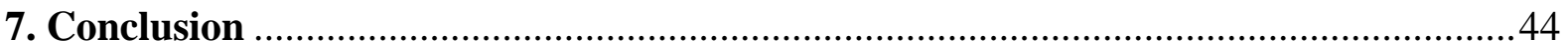




\section{Introduction}

"Financial technology" or "FinTech" refers to the use of technology to deliver financial solutions. The term's origin can be traced to the early 1990s and referred to the "Financial Services Technology Consortium", a project initiated by Citigroup in order to facilitate technological cooperation efforts. ${ }^{1}$ However, it is only since $2014^{2}$ that the sector has attracted the focused attention of regulators, industry participants and consumers alike. The term now refers to a large and rapidly growing industry representing between US\$12 billion ${ }^{3}$ and US\$197 billion ${ }^{4}$ in investment as of 2014, depending on whether one considers start-ups (FinTech 3.0) or traditional financial institutions (FinTech 2.0). ${ }^{5}$ This rapid growth has attracted greater regulatory scrutiny, which would seem warranted given the fundamental role FinTech plays in the functioning of finance and its infrastructure.

FinTech today is often seen as a uniquely recent marriage of financial services and information technology. However, the interlinkage of finance and technology has a long history. In fact, financial and technological development have long been intertwined and mutually reinforcing. The Global Financial Crisis of 2008 was a watershed and is part of the reason FinTech is now evolving into a new paradigm. ${ }^{6}$ This new evolution poses challenges for regulators and market participants alike, particularly in balancing the potential benefits of innovation with the potential risks. The challenge of this balancing act is nowhere more acute than in the developing world, particularly Asia. ${ }^{7}$

This paper analyses the evolution of, and outlook for, the FinTech sector and considers the regulatory implications of its growth. It does so by first considering the interlinked evolution of financial services and technology, in particular information technology. The FinTech

\footnotetext{
${ }^{1}$ See Marc Hochstein, "Fintech (the Word, That Is) Evolves" (5 October 2015) The American Banker available at 〈http://www.americanbanker.com/bankthink/fintech-the-word-that-is-evolves-1077098-1.html〉

${ }^{2}$ A Google trend search reveals that the interest over time for the word "FinTech" increased exponentially in 2014, available at $\langle$ https://www.google.com/trends/explore\#q=fintech >

${ }^{3}$ See Chloe Wang, "Financial technology booms as digital wave hits banks, insurance firms" (28 May 2015) Channel News Asia, available at <http://www.channelnewsasia.com/news/business/singapore/financialtechnology/1875644.html>

${ }^{4}$ See Gareth Lodge, Hua Zhang and Jacob Jegher, "IT Spending in Banking: A Global Perspective" (5 February 2015) Celent, available at $\langle$ http://www.celent.com/reports/it-spending-banking-global-perspective-2>

${ }_{5}$ The reason behind the range will be explained in the paper and comes from the distinction between FinTech 2.0 and FinTech 3.0

${ }^{6}$ See Douglas W. Arner, Janos Barberis, "Regulation of FinTech Innovation: A Balancing Act" (1 April 2015) available at <http://www.law.hku.hk/aiifl/regulating-fintech-innovation-a-balancing-act-1-april-1230-130-pm/>

${ }^{7}$ See Ray Chan, "Asian Regulator Seek FinTech Balance" (4 September 2015) Finance Asia, available at $<\underline{\text { http://www.financeasia.com/News/401588, asian-regulators-seek-fintech-balance.aspx }>}$
} 
environment is then explored in the broader evolutionary context, which is necessary to understand its current status and possible future development (sections 2 to 4). The evolutionary analysis is then used to develop a topology of the FinTech landscape today (section 3), focusing particularly on the impact of the Global Financial Crisis of 2008 and related post-crisis regulatory developments. Section 5 considers the example of the developing world, particularly Africa and Asia Pacific, where FinTech developments have become a central feature of financial market development. Section 6 highlights the necessity for regulators to interact pro-actively with industry so as to perform and uphold their mandates, in particular through the development of "regulatory technology" or "RegTech". The final section seeks to provide a framework to understand how a balancing between financial technology and regulation can be achieved.

\section{FinTech: New Term for an Old Sector}

At the broadest level, FinTech refers to the application of technology to finance. This definition gives rise to three specific observations.

First, FinTech is not an inherently novel development for the financial services industry. Indeed, the introduction of the telegraph (first commercial use in 1838$)^{8}$ and the laying of the first successful transatlantic cable in $1866^{9}$ (by the Atlantic Telegraph Company) provided the fundamental infrastructure for the first major period of financial globalization in the late $19^{\text {th }}$ century. This period is usually seen as running from around 1870 , with the laying of the transatlantic cable and other similar connections to the onset of the First World War. Subsequently, the introduction of the Automatic Teller Machine (ATM) in 1967 by Barclays Bank $^{10}$ arguably marks the commencement of the modern evolution of today's FinTech. The impact of ATMs led Paul Volcker, former chairman of the US Federal Reserve (1979-1987), in commenting on the role of financial innovation in the Global Financial Crisis of 2008, to famously say in 2009:

\footnotetext{
${ }^{8}$ See G. Barbiroli, "The Dynamic of Technology: A Methodological Framework for Tehcno-Analyse" (1997) Springer, page 58

${ }^{9}$ See Jill Hills, "The Struggle for Control of Global Communication: The formative Century" (2002) University of Illinois Press, page 35

${ }^{10}$ See Thomas Lerner, "Mobile Payment" (2013) Springer, page 3
} 
The most important financial innovation that I have seen the past 20 years is the automatic teller machine, that really helps people and prevents visits to the bank and it is a real convenience. ${ }^{11}$

Second, the financial services industry has been one of the prime purchasers of IT products and services globally, with total spending at over US\$ 197 billion in 2014 . $^{12}$ This is not a recent trend and dates back to the mid-1990s, when the financial services industry became the single largest purchaser of IT, a position it retains to this day. Thus, for at least twenty years, traditional financial services have been a driving force in the IT industry and this trend is not slowing as the industry is in fact predicted to double its IT spending. ${ }^{13}$ Since the late $1980 \mathrm{~s}$, finance has been an industry based upon transmission and manipulation of digital information. The ATM in fact is often the only point for most consumers today at which finance transitions from a purely digital experience to one that involves a physical commodity (i.e. cash).

Third, the term FinTech is not confined to specific sectors (e.g. financing) or business models (e.g. peer-to-peer (P2P) lending), but instead covers the entire scope of services and products traditionally provided by the financial services industry, a topic discussed in greater detail in section 4.

This historical perspective, however, does not explain the reason for the increase in activity and rising concerns of policy-makers ${ }^{14}$ or the industry itself. ${ }^{15}$ As "FinTech" is not a new story, its opportunities, risks and legal implications should not be novel; and, such is the case,

\footnotetext{
${ }^{11}$ See Paul Volcker, "The Only thing useful banks have invented in 20 years in the ATM" (13 December 2009) The New York Post, available at: <http://nypost.com/2009/12/13/the-only-thing-useful-banks-have-invented-in20-years-is-the-atm/>

${ }^{12}$ See Gareth Lodge, Hua Zhang and Jacob Jegher, "IT Spending in Banking: A Global perspective" (5 February 2015) Celent, available at: 〈http://www.celent.com/reports/it-spending-banking-global-perspective-2〉

${ }^{13}$ See Elliot Holley, "Digitalisation will double bank IT spending in next four years" (23 September 2015) Banking Technology, available at <http://www.bankingtech.com/374051/digitalisation-will-double-bank-itspending-says-gartner/>

${ }^{14}$ The UK government Chief Technology Advisor looking at the implications and benefits of FinTech from a regulatory standpoint; ${ }^{14}$ the Monetary Authority of Singapore (MAS) announcing a US\$ 160 million investment for research into the topic. See Shiwen Yap, "MAS commits \$225million to FinTech growth in Singapore" (2 July 2015) Deal Street Asia, available at: <http://www.dealstreetasia.com/stories/mas-commits-225m-to-fintechgrowth-in-singapore-8637/>

${ }^{15}$ Goldman Sachs estimating FinTech industry puts US\$ 4 trillion of revenues at risk. See Anna Irrera, "FN FinTech Focus: Disruptor's \$4tr fortune” (20 March 2015) Efinancial News, available at <http://thetally.efinancialnews.com/2015/03/fn-fintech-focus-much-finance-incumbents-stand-lose-disruptors/>
} 
as in 1985 in Electronic Banking: The Legal Implications, ${ }^{16}$ Sir Roy Goode and others considered the legal consequences of the increased use of electronic payments and authentications in banking. Rather, the current concerns of policy makers and industry arise not from the technology itself but from who is applying the technology to finance. Since 2008 there has been rapid expansion in the types of businesses that create and deliver technology to provide financial services and products. ${ }^{17}$

It is important to distinguish three main eras of FinTech evolution. From around 1866 to 1987, the financial services industry, while heavily interlinked with technology, remained largely an analogue industry, at least in public perception, a period which we characterize as FinTech 1.0. By 1987 at the latest, however, financial services at least in developed countries had become not only once again highly globalized, but also digital. This period, which we characterize as FinTech 2.0, continued until 2008. During this period, FinTech was dominated primarily by the traditional regulated financial services industry that used technology to provide financial products and services. However, since 2008 (the period we characterize as "FinTech 3.0") this is no longer necessarily the case. New start-ups and established technology companies have begun to deliver financial products and services directly to businesses and the general public.

\subsection{FinTech 1.0 (1866-1987): From analogue to digital}

As noted at the outset, finance and technology have long been interlinked and mutually reinforcing from their earliest stages of development. Finance has its origins in administrative systems for state administration necessary in the transition from hunter-gather groups to settled agricultural states, for instance in the context of Mesopotamia, in which some of the earliest examples of written records evidence financial transactions. ${ }^{18}$ Thus, there has been a clear linkage between finance and technology, in this instance from the mutually reinforcing process of the development of finance and written records, one of the earliest forms of information technology. Similarly, the development of money itself and finance are clearly

\footnotetext{
${ }^{16}$ R. M. Goode \& Institute of Bankers (Great Britain), "Electronic banking: The legal implications" (1985) London: Institute of Bankers.

${ }^{17}$ See Douglas W. Arner, Janos Barberis, "Regulation of FinTech Innovation: A Balancing Act" (1 April 2015) AIIFL available at <http://www.law.hku.hk/aiifl/regulating-fintech-innovation-a-balancing-act-1-april-1230$130-\mathrm{pm} />$

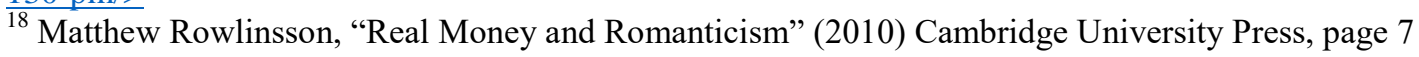


intertwined, with fiat currency (a technology evidencing transferable values) ${ }^{19}$ being one of the defining characteristics of a modern economy as well as one of the core areas of FinTech today. One sees a similar process in the emergence of early technologies for calculation such as the abacus and of course numbers and mathematics themselves. This evolutionary development can also be seen in the context of trade, with finance evolving from an early stage both to support trade (e.g. financing and insuring ships and infrastructure such as bridges, railroads and canals) as well as in supporting the production of goods for that trade. Certainly, double entry accounting ${ }^{20}$ - another technology fundamental to a modern economy - emerged from the intertwined evolution of finance and trade in the late Middle Ages and the Renaissance.

Many historians today share the view that the financial revolution in Europe in the late 1600s involving joint stock companies, insurance and banking, played an essential role in the Industrial Revolution. ${ }^{21}$ In this context, finance supported the development of technologies that underpinned industrial development.

\subsubsection{The first age of financial globalization}

In the late $19^{\text {th }}$ century finance and technology combined to produce the first period of financial globalization that lasted until the beginning of the First World War. During this period, technology such as the telegraph, railroads, canals and steamships underpinned financial interlinkages across borders, allowing rapid transmission of financial information, transactions and payments around the world. The financial sector at the same time had provided the necessary resources to develop the telegraphs, railroads, canals, steamships and other technologies. J.M. Keynes, writing in 1920, gave a clear picture of the interlinkage between finance and technology in this first age of financial globalization:

\footnotetext{
${ }^{19}$ Indeed, one can make the argument that paper is a technology that allows to store value. The same size bank note can "store" US\$10 or US\$100 and be worth this much as long as there is a state or central bank guaranteeing the bearer of the note to be paid. Thus the amount written on the bank note itself has theoretically no limit, indeed Zimbabwe is (in)famously known for have a Z\$ 100 trillion $(100,000,000,000,000)$ bank note.

${ }^{20}$ On the accounting side, the blockchain technology is akin to the double entry book keeping system, as any transaction processed via the blockchain is registered and sent to the whole network which can then be reaccessed for auditing purposes. Importantly and unlike traditional book keeping, because blockchain accounting is decentralized the capacity to fake a transaction is very complicated as it would require to amend the record on the whole blockchain network, which is not only complicated but very costly and thus may remove the economic rational of the fraud. See Matthew Spoke, "How Blockchain Tech Will Change Auditing for Good" (11 July 2015) Coin Desk, available at 〈http://www.coindesk.com/blockchains-and-the-future-of-audit/>

${ }^{21}$ Charles Moore, "Understanding the industrial Revolution" (2002) Routledge, page 36
} 
The inhabitant of London could order by telephone, sipping his morning tea in bed, the various products of the whole earth, in such quantity as he might see fit, and reasonably expect their early delivery upon his door-step; he could at the same moment and by the same means adventure his wealth in the natural resources and new enterprises of any quarter of the world, and share, without exertion or even trouble. ${ }^{22}$

\subsubsection{The early post-war period}

During the post-war period, while financial globalization was constrained for several decades, technological developments, particularly those arising from wartime, proceeded rapidly, especially in communications and information technology. In the context of information technology, code-breaking tools were developed commercially into early computers by firms such as International Business Machines (IBM), and the handheld financial calculator was first produced by Texas Instruments in $1967 .^{23}$ The 1950 s also marked the period where Americans were introduced to credit cards (Diners' Club, in 1950, Bank of America and American Express in 1958). ${ }^{24}$ This consumer revolution was further supported by the initial establishment of the Interbank Card Association (now MasterCard) in the US in $1966 .{ }^{25}$ By 1966, a global telex network was in place, providing the fundamental communications necessary on which to build the next stage of FinTech development. The first commercial version of the successor of the telex, the fax machine, was introduced by the Xerox Corporation in 1964 under the name of Long Distance Xerography (LDX). ${ }^{26}$ As noted previously, 1967 marked the deployment of the first ATM by Barclays in the UK.

\subsubsection{The modern foundations: $1967-1987$}

The launch of the calculator and the ATM in 1967 began the modern period of FinTech 1.0. 1967-1987 was a time when financial services moved from an analogue to a digital industry.

\footnotetext{
${ }^{22}$ John Maynard Keynes, The Economic Consequences of the Peace, 1920, pp. 10 -12.

23 See Patrick Thibodeau, "TI's first handheld calculator is now a museum piece" (26 September 2007) Computer World, available at <http://www.computerworld.com/article/2541155/computer-hardware/ti-s-firsthandheld-calculator-is-now-a-museum-piece.html $>$

${ }^{24}$ Jerry W. Markham, "A Financial History of the United States: From Christopher Columbus to the Robber Barons" (2002) M.E. Sharpe, page 306

${ }^{25}$ A good recollection of the history of the credit card industry was covered by Ben Woolsey and Emily Starbuck Gerson, "The History of Credit Cards" (11 May 2009) Credit Cards available at <http://www.creditcards.com/credit-card-news/credit-cards-history-1264.php >

26 Similarly, "The History of Fax: from 1983 to present days" provides a comprehensive perspective on the origin and evolution of the technology. Available at <http://faxauthority.com/fax-history/>
} 
Key developments set the foundations for the second period of financial globalization, which were clearly signposted by the global reaction to the 1987 stock market crash in the US.

In the area of payments, the Inter-Computer Bureau was established in the UK in 1968, forming the basis of today's BACS (Bankers' Automated Clearing Services), ${ }^{27}$ while the US CHIPS (Clearing House Interbank Payments System) was established in 1970. Fedwire, originally established in 1918, became an electronic instead of a telegraphic system in the early 1970s. Reflecting the need to interconnect domestic payments systems across borders, SWIFT (Society of Worldwide Interbank Financial Telecommunications) was established in $1973,{ }^{28}$ followed soon after by the collapse of Herstatt Bank in 1974, which clearly highlighted the risks of increasing international financial interlinkages, particularly through the new payments system technology. This crisis triggered the first major regulatory focus on FinTech issues in the form of a series of international soft law agreements on developing robust payments systems and related regulation. The combination of finance, technology and appropriate regulatory attention is the basis of today's US\$ 5.4 trillion a day global foreign exchange market, ${ }^{29}$ the largest, most global and most digitized component of the global economy.

In the area of securities, the establishment of NASDAQ ${ }^{30}$ in the US in $1971^{31}$, and the end of fixed securities commissions and the eventual development of the National Market System marked the transition from physical trading of securities dating to the late 1600s to today's fully electronic securities trading. In the consumer area, online banking was first introduced in the US in 1980 (although abandoned in 1983) and in the UK in 1983 by the Nottingham Building Society (NBS). ${ }^{32}$

\footnotetext{
${ }^{27}$ Brian Welch, "Electronic Banking and Treasury Security" (1999) Elsevier, page 48

${ }^{28}$ See SWIFT, "SWFIT History" (2014) available at

〈http://www.swift.com/about swift/company_information/swift_history>

${ }^{29}$ See Jessica Mortimer, "Table-Global FX Volume reaches \$5.3 trillion a day in 2013" (5 Sept 2013) Reuters, available at 〈http://www.reuters.com/article/2013/09/05/bis-survey-volumes-idUSL6N0GZ34R20130905>. By comparison in Hong Kong at the same period it was \$274 billion that was exchanged every day (Dec 2013) HKMA, available at <http://www.hkma.gov.hk/media/eng/publication-and-research/quarterlybulletin/qb201312/fa2.pdf>

${ }^{30}$ (acronym for National Association of Securities Dealers Automated Quotations)

31 See NASDAQ, "Celebrating 40 years of NASDAQ: from 1971 to 2011" (2011) NASDAQ, available at <http://www.nasdaq.com/includes/celebrating-40-years-nasdaq40-from-1971-to-2011.aspx>

${ }^{32}$ Harry Choron and Sandy Choron, "Money: Everything You Never Knew About Your Favorite Thing to Find, Save, Spend \& Covet" (2011) Chronicle Books, page 22
} 
Throughout this period, financial institutions increased their use of IT in their internal operations, gradually replacing most forms of paper-based mechanisms by the 1980s, as computerization proceeded and risk management technology developed to manage internal risks. One early example of a form of FinTech innovation is very familiar today to financial professionals. Michael Bloomberg started Innovation Market Solutions (IMS) in 1981 after leaving Solomon Brothers, where he had designed in-house computer systems. ${ }^{33}$ By 1984 , Bloomberg terminals were in ever-increasing usage among financial institutions.

Traditional financial services firms are thus clearly a central aspect of FinTech. As Yang Kaisheng CEO at Industrial and Commercial Bank of China (ICBC), the largest bank in the world by market share and asset size, has recently observed:

There is a perception that when banks develop internet technology, it is not regarded as FinTech. Some people say this is a new idea, a new ideology that will get rid of agents and intermediaries and that banks can't adapt. ${ }^{34}$

As one example, approximately one third of Goldman Sachs' 33,000 staff are engineers more than LinkedIn, Twitter or Facebook. ${ }^{35}$ Paul Walker, Goldman Sachs' global technology co-head that they "were competing for talents with start-ups and tech companies"36

\section{FinTech 2.0 (1987-2008): Development of Traditional Digital Financial Services}

1987 marked a new period of regulatory attention to the risks of cross-border financial interconnections and their intersection with technology. One of the iconic images from this period is that of the investment banker wielding an early mobile telephone (first introduced in the US in 1983) perfectly illustrated in Oliver Stone's film Wall Street in 1987. That same year also marks the "Black Monday" stock market crash whose effect on markets around the world clearly showed they were interlinked through technology in a way not seen since the 1929 crash. While almost 30 years later there is still no clear consensus on the causes of the crash, much focus at the time was placed on the use by financial institutions of computerized trading systems which bought and sold automatically based on pre-set price levels ("program

\footnotetext{
33 IMS was called a "Financial Information" company and not yet a "Financial Technology" company. See Benjamin Wachenje, "Michael Bloomberg: Wall Street Data Pioneer and ex-NYC Major (29 April 2014) CNBC, available at <http://www.cnbc.com/2014/04/29/25-michael-bloomberg.html >

${ }^{34}$ See Jame DiBiasio, "ICBC Chairman welcomes FinTech Reg" (17 August 2015) Finance Asia, available at <http://www.financeasia.com/News/400732,icbc-chairman-welcomes-fintech-regs.aspx >

${ }^{35}$ See, Jonathan Marino, "Goldman Sachs is a Tech Company" (12 April 2015) Business Insider, available at $<$ http://www.businessinsider.com/goldman-sachs-has-more-engineers-than-facebook-2015-4>

${ }^{36}$ Ibid
} 
trading"). The reaction led to the introduction of a variety of mechanisms, particularly in electronic markets, to control the speed of price changes ("circuit breakers"). It also led securities regulators around the world to begin working on mechanisms to support cooperation, in the way that the 1974 Herstatt crisis and the 1982 developing country debt crisis triggered greater cooperation between bank regulators in respect to cross-border issues.

In addition, the Single European Act of 1986 came into effect, establishing the framework for the establishment of a single financial market in the European Union (from 1992), and the Big Bang financial liberalization process in the UK in 1986, combined with the 1992 Maastricht Treaty and an ever increasing number of financial services Directives and Regulations from the late 1980s, set the baseline for the eventual full interconnection of EU financial markets by the early $21^{\text {st }}$ century.

Certainly, by the late 1980s, financial services had become largely a digital industry, based on electronic transactions between financial institutions, financial market participants and customers around the world, with the fax largely having supplemented the telex. By 1998, financial services had become for all practical purposes the first digital industry. This time also showed the initial limits and risks in complex computerized risk management systems (e.g. Value at Risk (VaR)), with the collapse of Long-term Capital Management (LTCM) in the wake of the Asian and Russian financial crises of 1997-1998.

However, it was the emergence of the Internet that set the stage for the next level of development, beginning in 1995 with Wells Fargo using the World Wide Web (WWW) to provide online account checking. ${ }^{37}$ By 2001 , eight banks in the US had at least one million customers online, with other major jurisdictions around the world rapidly developing similar systems and related regulatory frameworks to address risk. By 2005, the first direct banks without physical branches emerged (e.g. ING Direct, HSBC Direct) in the UK.

By the beginning of the $21^{\text {st }}$ century, both banks' internal processes, interactions with outsiders and an ever increasing number of their interactions with retail customers had become fully digitized, facts highlighted by the significance of IT spending by the financial services industry. In addition, regulators were ever more using technology, especially in the

\footnotetext{
${ }^{37}$ See Charles Riggs, "Wells Fargo: 20 Years of internet Banking" (18 May 2015) Wells Fargo, available at <https://blogs.wellsfargo.com/guidedbyhistory/2015/05/internet-20-years/>
} 
context of securities exchanges, which by 1987 had become the most common source of information regarding market manipulation, based upon their computerized trading systems and records.

\subsection{Regulatory approaches to traditional DFS in FinTech 2.0}

As an example of regulatory interest in related developments, David Carse, then Deputy Chief Executive of the Hong Kong Monetary Authority (HKMA), gave a keynote address in 1999 where he considered the new regulatory framework needed for e-banking. ${ }^{38}$ It is important to note that this speech was given in 1999, whilst e-banking had been around since 1980.

This time lag highlights the delay in regulatory reaction to technological changes. This lag is to be expected, and often welcomed as it is consistent with efficient market regulation. ${ }^{39}$ There is limited benefit in regulating all new innovations applicable to the financial sector. ${ }^{40}$ Pre-emptive regulation would not only increase the workload of regulatory agencies and tend to stifle innovation severely, but would also have limited benefits. Therefore, regulatory reaction is to be expected and can arguably be beneficial in allowing the emergence of a new industry or channel.

The regulatory view during FinTech 2.0 was that whilst e-banking was simply a digital version of the traditional brick and mortar banking model, it did create new risks. By providing direct and virtually unlimited access to their accounts, technology removed the necessity for depositors to be physically present at a branch to withdraw funds. Indirectly, this could facilitate electronic bank runs as the lack of physical interaction removes the friction from a withdrawal. In turn this can increase the stress on a financial institution that has liquidity problems during a banking crisis:

\footnotetext{
${ }^{38}$ David Carse, "Keynote: Regulatory Framework of e-banking" (8 October 1999) HKMA, available at <http://www.bis.org/review/r991012c.pdf>

${ }^{39}$ For more details on this point please see section 6.2

${ }^{40}$ In this respect, it is useful to compare Hong Kong to the Singaporean approach. Indeed, whilst the Octopus Card Network (contactless store value facility) has been mainly developed by the private sector, its Singaporean equivalent ENZ-Link was pushed as the standard by the government. In other words, whilst Hong Kong regulators tend to be more technology agnostic, Singapore seems to be driven more by a top-down vision on the use of technology within the country. This observation would also echo the current developments within FinTech whereby Singapore has been much more public as to the government initiatives in that space (e.g. US\$ 225 million to be invested in research to $75 \%$ of operating cost of FinTech accelerators subsidized).
} 
An internet-based bank is faced with the same types of banking risk as its traditional counterparties. In some ways, the internet may heighten these risks. For example, the ability to transfer funds between different bank accounts may increase deposit volatility and could, in extreme situations, lead to "virtual bank runs". Banks will need to build this possibility into their liquidity management policies. ${ }^{41}$

Regulators also identified that online banking creates new credit risks. Through the removal of the physical link between the consumer and the bank, it was anticipated that competition would increase (e.g. borrowers would have access to a greater pool of lenders as they were no longer limited to a specific geographical location). Whilst prima facie positive for consumers, this competitive pressure may also be problematic from a financial stability point of view. The US provided a telling example of this with the deregulation of its banking market during the 1980s. ${ }^{42}$ Second, the constraints arising from being known personally by a loan officer are lost as the loan origination decision may be replaced by an automated system.

On the beneficial side, it was rightly noted that better organized data could lead to an improved understanding of the borrowers' true credit risk and allow the offering of products better aligned to the risk profile of the consumer. This insight pre-empted the emergence of big-data analysis that provides more granular insights into consumers' profiles. ${ }^{43}$ However, the comparison stops here, because Carse's speech was built on the premise that these technological innovations would be used by licensed financial intuitions only. This distinction is key to understanding the turning point between FinTech 2.0 and FinTech 3.0.

\footnotetext{
41 David Carse, "Keynote: Regulatory Framework of e-banking" (8 October 1999) HKMA, page 4 <http://www.bis.org/review/r991012c.pdf >

${ }^{42}$ The preamble of the Depository Institutions Deregulation and Monetary Control Act [1980] "provides for the gradual elimination of all limitations on the rates of interest". In practice this meant that interest payable on deposits was now freely set by the market as opposed to being capped by regulations. The purpose of this legislation was to allow for retail banks to compete more equally with Money Market Funds (MMF) that increasingly attracted consumers' deposits, given the better return. However, it also had the unintended consequence of removing the bank's guaranteed profit generated by the spread between interest payable (e.g. deposits) and chargeable (e.g. loans). In turn this forced banks to make up for the loss in revenue, previously guaranteed by the cap of interest rates, by shifting towards higher risk activities (e.g. sub-prime lending) or moving away from interest-based income (e.g. fees generated by loan securitization).

${ }^{43}$ This vision of a data-led regulatory system is not new. Back in 2009 the SEC created the division for Economic and Risk Analysis under the supervision of Henry $\mathrm{Hu}^{43}$, looking at driving data insight for better regulation. However, it seems clear that since 2007 there has been an increase in activity emanating from regulators, industry and academia alike on this topic. For more details on RegTech please refer to Douglas Arner and Janos Barberis chapter "FinTech in China: From Shadow Banking to P2P Lending", in Banking Beyond Banks \& Money" (Springer 2015 forthcoming).
} 
During this FinTech 2.0 period, the expectation was that the providers of e-banking solutions would be supervised financial institutions. Indeed, the use of the term "bank" in most jurisdictions is restricted to companies duly authorized or regulated as financial institutions. ${ }^{44}$

However, the Fintech 3.0 era has shown that financial services provision may no longer solely rest with regulated financial institutions. The provision of financial services by nonbanks may also mean there are no effective home regulators to act on the concerns of host regulators, and thus whether the provider is regulated or not may make little difference. This means that the last safeguard may come from consumer education and distrust of placing funds with a non-bank, off-shore institution.

Yet, even this last constraint has been undermined since 2007, when the brand image of banks and their perceived stability was shaken to the core. A 2015 survey reported that American trust levels in technology firms handling their finances is not only on the rise, but actually exceeds the confidence placed in banks. ${ }^{45}$ For example, the level of trust Americans have in CitiBank is 37\%, whilst trust in Amazon and Google respectively reaches $71 \%$ and $64 \%$. Of course, Amazon and Google are massive, well-established corporations. Nonetheless, there is an increasing number of non-listed companies and young start-ups that are handling customers' money and financial data. China provides a clear illustration of this phenomenon, ${ }^{46}$ with over 2,000 $\mathrm{P} 2 \mathrm{P}$ lending platforms operating outside of a clear regulatory framework. ${ }^{47}$ This does not deter millions of lenders and borrowers alike, who are willing to place or borrow billions on these platforms due to the cheaper cost, better return and increased convenience. Likewise, the "reputational" factors that mean only banks can offer banking services are not relevant for a large proportion of people in the developing world.

\footnotetext{
${ }^{44}$ See the sensitive words for UK company formations issued by the Companies House. The terms "banc", "bank" or "banking" are restricted unless authorised by the Financial Conduct Authority Sensitive Business Name team. See page 33, <https://www.gov.uk/government/uploads/system/uploads/attachment_data/file/418150/GP1_Incorporation_na mes_v5 4-ver0.29-4.pdf>.

${ }^{45}$ See LTP Team, "Survey shows Americans trust technology firms more than banks and retailers" (25 June 2015) Let's talk payment, accessible via <http://letstalkpayments.com/survey-shows-americans-trusttechnology-firms-more-than-banks-and-retailers/>.

${ }^{46}$ For a more in depth analysis of Financial Technology developments in China, see Weihuan Zhou, Douglas W. Arner \& Ross P. Buckley "Regulation of Digital Financial Services in China: From last mover to first mover?" (Sept 2015) available at $\langle$ http://ssrn.com/abstract=2660050>. For the more specific topics of shadow banking and P2P lending, see Douglas W. Arner \& Janos Barberis, "FinTech in China: From Shadow Banking to P2P lending", in Banking Beyond Banks \& Money" (Springer 2015 forthcoming).

${ }^{47}$ It is recognized that regulators in China (e.g. CBRC and PBOC) are due to announce new rules around the $\mathrm{P} 2 \mathrm{P}$ industry mainly around credit-worthiness checks and regulatory capital requirements.
} 
For over 1.2 billion unbanked individuals, this factor is weak, as to them banking may well be a commodity that can be provided by any institution, whether regulated or not.

In other words, in developing markets there may well be a lack of "behavioral legacies" 48 whereby the public expects that only banks can provide financial services. For these populations, "banking is essentials, banks are not," as it was rightly captured by Bill Gates in 1994. ${ }^{49}$

\section{FinTech 3.0 (2009 - present): Democratizing Digital Financial Services?}

A mindset shift has occurred from a retail customer perspective as to who has the resources and legitimacy to provide financial services. Whilst it is difficult to identify how and where that trend started, it is possible to say that the 2008 Global Financial Crisis represents a turning point and has catalyzed the growth the FinTech 3.0 era. ${ }^{50}$

As the remainder of this section will show, post-2008 an alignment of market conditions supported the emergence of innovative market players in the financial services industry. Among these factors are: public perception, regulatory scrutiny, political demand and economic conditions. Each of these points is now explored within a narrative that illustrates how 2008 acted as turning point and created a new group of actors applying technology to financial services.

\subsection{FinTech and the Global Financial Crisis: Evolution or revolution?}

The financial crisis has had two major impacts in terms of public perception and human capital. First, as the origin of the financial crisis became more widely understood, the public perception of banks deteriorated. For example, predatory lending methods targeting

\footnotetext{
${ }^{48}$ The term "behavioural legacies" echoes the "IT legacy systems" of banks that prevent them to fully digitize their process given the fact that their system are too-old-to-upgrade and too-expensive-to-replace. Indeed, until now most of banks IT spending was in maintenance as opposed to upgrade, however this gradually changing.

${ }^{49}$ See Falk Rieker, "Does the future need banks?" (2 April 2013) SAP, available at $\langle$ http://blogs.sap.com/banking/2013/04/02/does-the-future-need-banks/>

${ }^{50}$ As it will be discussed in section 5.2, China's FinTech development has a different origin, thus it as FinTech 3.5 .
} 
disenfranchised communities not only breached the consumer protection obligations of banks, but also severely damaged their standing. ${ }^{51}$

Second, as the financial crisis morphed into an economic crisis, an estimated 8.7 million American workers lost their jobs. ${ }^{52}$ Two sets of individuals were impacted by the financial crisis. On the one hand, the general public developed a distrust of the traditional banking system. On the other hand, many financial professionals either lost their jobs or were now less well compensated. This under-utilized educated workforce found a new industry, FinTech 3.0, in which to apply their skills. ${ }^{53}$ Last but not least, there is also the newer generation of highly educated, fresh graduates facing a difficult job market. Their educational background has often equipped them with the tools to understand financial markets, and their skills can be applied to FinTech 3.0.

Post-financial crisis regulation has increased the compliance obligations of banks and altered their commercial incentives and business structures. In particular, the universal banking model has been directly challenged ${ }^{54}$ with ring-fencing obligations and increased regulatory capital changing the incentive or capacity of banks to originate low-value loans. Furthermore, the (mis)use of certain financial innovations, such as collateralized debt obligations (CDOs), has been regarded as a contributor to the crisis by detaching the credit risk of the underlying loan from the loan originator. Finally, the necessity to ensure orderly failure of banks has driven the implementation of financial institution resolution regimes across jurisdictions, which required banks to prepare Recovery and Resolution Plans (RRPs) and conduct stress tests to evaluate their viability. ${ }^{55}$ As a result, since 2007 , the business models and structures of banks have been re-shaped.

\footnotetext{
${ }^{51}$ Sumit Agarwal et al. "Predatory lending and the subprime crisis" (2014) Journal of Financial Economics, p. 1 available at $\langle$ http://www.ushakrisna.com/2401.pdf $>$

52 See John Kell, "U.S. Recovers all jobs lost in Financial Crisis" (6 June 2014) Fortune, available at <http://fortune.com/2014/06/06/us-jobs-may/>

${ }^{53}$ On that note, Mark Esposito and Terence Tse discuss the social impact of the crisis on the European young work force. See "The lost generation: what is true about the myth..." (7 April 2014) LSE, available at $<$ http://blogs.lse.ac.uk/eurocrisispress/2014/04/07/the-lost-generation-what-is-true-about-the-myth/>

${ }^{54}$ See Roberto Ferrari, "The end of Universal Banking Model" (2016) The FinTech Book, available at $<$ https://medium.com/the-fintech-book/the-end-of-universal-bank-model-a52964b21d48>

55 Janos Barberis, "The 2007 Metldown - A Legal Phenomenon" (2012) University of Birmingham, p. 60.
} 


\subsection{From post crisis regulation to FinTech 3.0}

These new regulatory obligations (e.g. Dodd Frank Act, Basel 3) are welcome in light of the social and economic impact of the financial crisis. It is now unlikely that the next financial crisis will be prompted by the same causes and impact the public is comparable ways. ${ }^{56}$ Yet, these post-crisis reforms had the unintended consequence of spurring the rise of new technological players and limiting the capacity of banks to compete.

For example, Basel 3 translated into increased capital requirements. Whilst this enhanced market stability and risk-absorbing capacity, it also diverted capital from SMEs or private individuals. The latter may then have to turn to $\mathrm{P} 2 \mathrm{P}$ lending platforms or other innovations to fulfil their need for credit.

From a political perspective, increased unemployment and reduced availability of credit can directly challenge the legitimacy of elected representatives. This is the political motivation behind the Jump Start Our Business (JOBs) Act in the United States in 2012. The JOBs Act tackles these issues of unemployment and credit supply in two ways. On employment, the JOBs Act aims to promote the creation of start-ups by providing alternative ways to fund their businesses. The preamble of the act, states:

An Act: To increase American job creation and economic growth by improving access to the public capital markets for emerging growth companies. $^{57}$

From a policy perspective, there is little down side in promoting entrepreneurship as it has a direct impact on job creation

On financing, the JOBs Act assisted start-ups to by-pass the credit contraction caused by banks' increased costs and limited capacity to originate loans. The JOBs Act made it possible for start-ups to raise directly the finance to support their business by raising capital in lieu of

\footnotetext{
${ }^{56}$ On what may cause the next crisis, and the inadequacy of regulatory reforms to date to avert it, see Ross P. Buckley, "Reconceptualizing Global Financial Regulation", (Oxford Journal of Legal Studies 2016 forthcoming).

57 Complete version of the Act is available on the following link <http://www.gpo.gov/fdsys/pkg/BILLS112hr3606enr/pdf/BILLS-112hr3606enr.pdf>
} 
equity on P2P platforms. Figure 1 below shows the sharp increase in financing availability on online platforms:

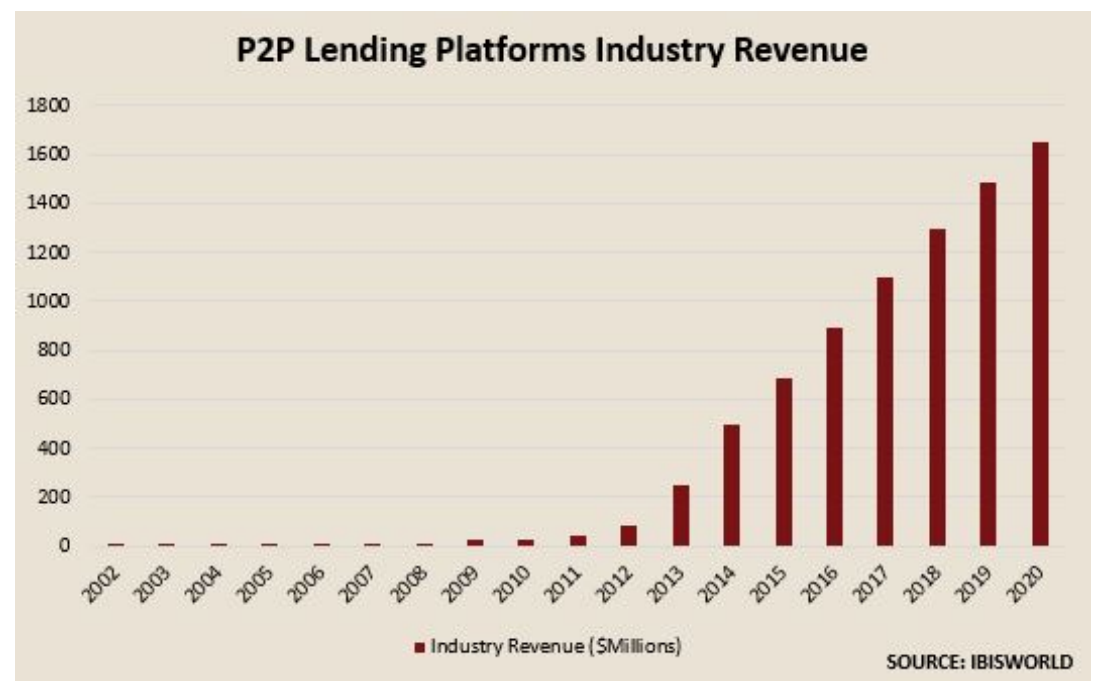

Figure 1: P2P lending platform industry revenue $\mathrm{g}^{58}$

The JOBs Act did not have the specific purpose of supporting FinTech 3.0, because it applied to start-ups in general. These alternative funding sources became available at a time that coincided with, on the one hand, increased regulatory pressures that limited banks' capacity to innovate, and, on the other hand, with a public perception of traditional banks and human talent outflow, which provided the necessary market and knowledge for new FinTech startups to emerge.

In summary, the financial services industry since 2008 has been affected by a "perfect storm", financial, political and public in its source, allowing for a new generation of market participants to establish a new paradigm known today as "FinTech".

\subsection{The FinTech industry today: A topology}

On the basis of this evolutionary analysis, it is possible to develop a comprehensive typology for the FinTech industry. FinTech today comprises five major areas: (1) finance and investment, (2) operations and risk management, (3) payments and infrastructure, (4) data security and monetization, and (5) customer interface. In addition to these is the use of technology in regulation itself, the subject of Section 6 below.

\footnotetext{
${ }^{58}$ See Omar Khedr, "Peer-to-Peer Lending Industry to grow by 37.7\% in 2015" (12 May 2015) Ibis World, available at < http://media.ibisworld.com/2015/05/12/peertopeerlendingrevenuetogrow/>
} 
Finance and investment: Much of the public, investors and regulatory attention today focuses on alternative financing mechanisms, particularly crowdfunding and P2P lending. However, FinTech clearly extends beyond this narrow scope to include financing of technology itself (e.g. via crowdfunding, venture capital, private equity, private placements, public offerings, listings etc.). From an evolutionary perspective, the 1990s tech bubble is a clear example of the intersection of finance and technology, as is NASDAQ, the dematerialization of the securities industry which has followed over the succeeding decades and the advent of program trading, high frequency trading and dark pools. Looking forward, in addition to continuing development of alternative financing mechanisms, FinTech is increasingly involved in areas such as robo-advisory services.

Financial operations and risk management: These have been a core driver of IT spending by financial institutions, especially since 2008 as financial institutions have sought to build better compliance systems to deal with the massive volume of post-crisis regulatory changes. From an evolutionary perspective, the development of finance theory and quantitative techniques of finance and their translation into financial institution operations and risk management was a core feature particularly of the 1990s and 2000s, as the financial industry built systems based upon VaR and other systems to manage risk and maximize profits. Going forward, this is clearly an area which is likely to continue to grow driven by costs and fines, an issue considered further in Section 6 below.

Payments and infrastructure: Internet and mobile communications payments are a central FinTech focus and have been a driving force particularly in developing countries, an issue discussed further in Section 5 as underpinning FinTech 3.5. Payments have been an area of great regulatory attention since the 1970s, resulting in the development of both domestic and cross-border electronic payment systems, that today support the US\$ 5.4 trillion per day global foreign exchange markets. Likewise, infrastructure for securities trading and settlement and for OTC derivatives trading continues to be a major aspect of the FinTech landscape, and are areas where IT and telecommunications companies are seeking opportunities to disintermediate traditional financial institutions.

Data security and monetization: These are key themes in FinTech today especially as both FinTech 2.0 and FinTech 3.0 start to exploit the monetary value of data. Following the GFC, 
it has become clear that the stability of the financial system is a national security issue. The digitized nature of the financial industry means it is particularly vulnerable to cybercrime and espionage, with the latter increasingly important in geopolitics. This digitization and consequent vulnerability is the result of decades of development, highlighted in previous sections, and, going forward, will remain a major concern for governments, policymakers, regulators and industry participants, as well as customers. ${ }^{59}$ At the same time, FinTech innovation is clearly present in the uses to which "big data" can be applied to enhance the efficiency and availability of financial services.

Consumer interface, particularly online and mobile financial services. This will continue to be a major focus of traditional financial services and non-traditional FinTech developments. This is another area in which established and new IT and telecommunications firms are seeking to contest directly with traditional financial services firms; and, interestingly, it may well be in developing countries where factors increasingly combine to support the next era of FinTech development. This vertical holds the highest potential of competition with the traditional financial sector, as this tech companies can leverage of their pre-existing large customer bases to roll out new financial products and services. ${ }^{60}$

\section{FinTech 3.5 in Emerging Markets: The Examples of Asia and Africa}

FinTech 3.0 emerged as a reaction to the financial crisis in the West, but in Asia and Africa recent FinTech developments have been primarily prompted by the pursuit of economic development. We characterize the era in these two regions as FinTech 3.5.

\footnotetext{
${ }^{59}$ Moody's , a credit rating agency, made clear that threats of cyberattack can negatively affect the credit profile of countries or institutions alike. See Global Credit Research, "Moody's: Threat of Cyber Attack on US Utilities cushioned by likelihood of government support" (15 October 2015) Moody's, available at <https://www.moodys.com/research/Moodys-Threat-of-cyber-attack-on-US-utilities-cushioned-by-PR 336640>

${ }^{60}$ For example, Facebook holds 49 Money Transmitter Licenses that would allow it to provide direct payment services to its 213 million active users across the US. To see the list of states where Facebook holds these licenses see <https://www.facebook.com/payments terms/licenses>. A similar case can be made about Tencent and its social network platform that has over 500 million users. Likewise, WeChat recently making available “in-app" loan applications up to US\$ 30,000. See Juro Osawa, “Tencent's WeChat App to Offer Personal Loans in Minutes" (11 September 2015) The Wall Street Journal, available at < $\underline{\text { http://www.wsj.com/articles/tencent-to- }}$ add-personal-loan-feature-to-wechat-app-1441952556>
} 


\subsection{FinTech opportunities and limitations in the Asia-Pacific Region}

To appreciate Asian FinTech developments one must look beyond reported investment figures as Accenture estimates that out of the US\$ 12 billion dollars in new investment in FinTech in 2014, only US\$ 700 million has been invested in the APAC region. ${ }^{61}$

Hong Kong and Singapore have seen the creation of three FinTech accelerators in less than a year, giving them one of the greatest concentrations of FinTech accelerators in the world. In Australia, a dedicated co-work space somewhat quaintly named Stone and Chalk received over 350 applications for 150 spaces. ${ }^{62}$ Korea is set to open an expanded version of Level 39 (London's prominent FinTech co-working space) in the coming months. On the regulatory side, most Asian regulators have initiated a FinTech strategy and met in Kuala Lumpur to discuss this alongside the World Capital Market Symposium in 2013. ${ }^{63}$

The growth rate of the market is attributable to various factors. On the institutional side, IT spending by traditional banks has lagged behind levels in Europe and the US. ${ }^{64}$ This can be explained by the slightly less competitive regional market, still heavily controlled and distorted by state owned banks. Public distrust of the state-owned banking system (due to corruption and inefficiency) means the public is quick to accept alternatives provided by nonbanks. In terms of infrastructure the branch network distribution in the APAC region is far less extensive than in Europe and the US. There are 62.5 branches per 100,000 people in

\footnotetext{
${ }^{61}$ See Melissa Volin and Farrell Sklerov, "Fintech Investment in U.S. Nearly tripled in 2014, according to report by Accenture and partnership fund for New York City (25 June 2015) Business Wire, available at <http://www.businesswire.com/news/home/20150625005146/en/Fintech-Investment-U.S.-Tripled-2014-ReportAccenture\#.VgqX2nqqpBc>

${ }^{62}$ See Simon Thomsen "FinTech Hub Stone \& Chalk is moving to bigger premises before it's even opened" (10 Jun 2015) Business Insider, available at <http://www.businessinsider.com.au/fintech-hub-stone-chalk-ismoving-to-bigger-premises-before-its-even-opened-2015-6 $>$

${ }^{63}$ See Ray Chan, "Asian regulators seek FinTech balance" (4 September 2015) Finance Asia, available at <http://www.financeasia.com/News/401588,asian-regulators-seek-fintech-balance.aspx >

${ }^{64}$ See Keiichi Aritomo, Driek Desmet and Andy Holley "More bank for your IT buck" (June 2014) McKinsey, available at 〈http://www.mckinsey.com/insights/business technology/more bank for_your_it_buck>
} 
Europe, but only 12.5 branches per 100,000 in APAC. ${ }^{65}$ As a result, mobile-based financial services and products are comparatively more attractive. ${ }^{66}$

For China, the above analysis is supported by the government market reform process initiated in the late 1970s. In less than 30 years, China has gone from a mono-banking model to over 80 banks and 2,000 P2P lending platforms. These figures do not include the additional five new private banks (e.g. Mybank, Webank) and the further 40 private banks that are expected. ${ }^{67}$ To put this in perspective, it took over a 150 years for a new retail banking license to be issued in the UK: Metro Bank in 2010. ${ }^{68}$ Furthermore, we should not expect growth to slow in China, especially with the government's recent Internet Finance Guidelines issued in July 2015. ${ }^{69}$ FinTech 3.5 in the developing world is supported by a strong underlying rationale, including, but not limited to, the following characteristics: (1) young digitally savvy populations equipped with mobile devices; (2) $60 \%$ of the world's middle class will be located in Asia by 2030; (3) inefficient financial and capital markets creating opportunities for informal alternatives; (4) shortage of physical banking infrastructure; (5) behavioral pre-disposition in favour of convenience over trust; (6) un-tapped market opportunities (1.2 billion people without bank accounts); and (7) less stringent data protection and competition. In addition, particularly in India and China, there are very large numbers of engineering and technology graduates.

These trends are further reinforced by the interaction of a dynamic private sector looking to expand into financial services and a public sector welcoming market reform and diversification to drive economic growth. The implication of all this is that FinTech development in Asia is not a new post-crisis paradigm but instead is a combination of entrepreneurial and regulatory forces.

\footnotetext{
${ }^{65}$ Janos Barberis, "The Rise of FinTech: Getting Hong Kong to lead the digital financial transition in APAC" (November 2014) FinTech HK, p. 13, available at $<$ http://www.fintech.hk/media/uploads/resources/reports/fintech.hk/2015/07/14/05 30_48/The\%20Rise\%20of\% 20FinTech\%20-\%20Nov\%20'14.pdf>

66 Ibid.

${ }^{67}$ See Kevin Yao and Matthew Miller, "China encourages privately-owned banks, allow more foreign competition" (26 June 2015) Reuters, available at $<$ http://www.reuters.com/article/2015/06/26/china-economybanks-idUSL3NOZC2LA20150626>

${ }^{68}$ See Jill Treanor, "UK Challenger banks aim to loosen grip of big four" (1 June 2015) The Guardian, available at $\langle$ http://www.theguardian.com/business/2015/jun/01/uk-challenger-banks-aim-to-loosen-grip-of-big-four $>$

${ }^{69}$ For more in depth analysis of Financial Technology developments in China see Weihuan Zhou, Douglas W. Arner and Ross P. Buckley "Regulation of Digital Financial Services in China: From last mover to first mover?" (Sept 2015) available at 〈http://ssrn.com/abstract $=2660050\rangle$
} 
The potential for opportunity needs to be balanced with the challenges specific to the market and the region. Investors and networks in APAC are less sophisticated than in developed Western markets. There are large information asymmetries in market activity. Second, financing is not readily attainable, as there are high barriers to entry to retail banking (e.g. regulatory capital requirements, ownership structures, and market restrictions). Furthermore, as companies scale, the fragmented regulatory regime puts B2C FinTech companies at a disadvantage compared with B2B companies, particularly those that sell to banks, as they partially shift the compliance burden to the client. ${ }^{70}$

The fragmented regime in APAC is also apparent when compared to Europe ( 24 countries in APAC compared to one harmonized market). Finally, financial engineering in APAC is less sophisticated than in the EU and US markets, which constrains certain FinTech companies. ${ }^{71}$ For example, robo-advisory platforms on wealth management build portfolios for clients with small amounts of money. However, the level of tranching of financial products in the region is not yet at a level that allows for efficient "micro-portfolio" creation led by algorithms.

Despite these limitations, it is clear that governments are beginning to adapt their policies and regulatory regimes to foster the development of FinTech companies. Efficient financial markets are directly linked to an increase in economic output, which is a key motivator for developed and developing countries. ${ }^{72}$

\subsection{China: Transitioning its financial market for the $21^{\text {st }}$ century}

For China specifically, technology has already blurred customer perceptions of who can deliver a financial service. The deposit of money for payments is no longer reserved to deposit accounts at banks. Holding client deposits traditionally has flagged an institution as a bank and attracted the concomitant licensing and regulatory obligations. However this no longer seems to be the case as China's AliPay processes over one million transactions each

\footnotetext{
${ }^{70}$ See Douglas W. Arner \& Janos Barberis, "Regulation of FinTech Innovation: A Balancing Act" (1 April 2015) AIIFL, available at <http://www.law.hku.hk/aiifl/regulating-fintech-innovation-a-balancing-act-1-april1230-130-pm/>

${ }^{72}$ Indeed, the announcement of the Payment System Directive 2 (PSD2) in Europe has been justified, amongst other reasons, by the fact that the fragmented rules in the payment industry in the European Union up to $1 \%$ of it GPD. If gained back, following the implementation of PSD2, this could boost the European economy. See Press Release, "New Rules on Payment Services for the Benefits of Consumers and Retailers" (24 July 2013) European Commission, available at <http://europa.eu/rapid/press-release IP-13-730_en.htm>
} 
day without being a bank. ${ }^{73}$ Payments can be made using deposits held in a Yu'E Bao ${ }^{74}$ account which yields an interest rate and is redeemable on-demand.

Regulators and legislators must face this fast-changing environment. Banks should be allowed $^{75}$ to respond directly to the competitive challenges of less regulated internet finance companies, that can gain significant market share ${ }^{76}$ by offering close substitutes for certain financial services. Unlike in the West, internet companies in China are a real threat to the market share of banks.

The benefits of internet finance companies require consideration. Alibaba has fulfilled two main government policy objectives by creating 2.87 million direct and indirect job opportunities, and providing over 400,000 SMEs with loans ranging from $\$ 3,000$ to $\$ 5,000$. $^{77}$ Regulators need to strike a difficult but important balance in the current competitive dynamic between banks and internet finance companies.

China has been gradually reforming its financial system since 1978. However, the Global Financial Crisis of 2008 slowed down the appetite of politicians and regulators for further large-scale reform, as the crisis deeply shook the understanding of what constitutes an effective financial system and how institutions should be regulated. Indeed, legislation since 2008 has reversed the trend towards a free market, by tightening the regulatory environment for banks in China. In the West, this is reflected by ever-increasing compliance costs from newly-passed national laws (such as Dodd-Frank) or international standards (such as Basel $3)$.

There is a unique opportunity in the technologically driven financial transition currently underway in China. As well as learning from regulatory mistakes in Western countries, China

\footnotetext{
${ }^{73}$ L. Shrader and E. Duflos, 'China: a New Paradigm in Branchless Banking' (March 2014), CGAP, p. 37 available at <http://www.cgap.org/sites/default/files/Working-Paper-China-A-New-Paradigm-in-BranchlessBanking-March-2014_0.pdf $>$

${ }^{74}$ Yu'E Bao is a service that offers Alipay customers the possibilities to invest their idle cash in money market funds. Those accounts are redeemable on demand and pay higher interest on "deposit" held.

${ }^{75}$ For example, by simplifying and changing certain regulatory constrains under which they operate (or alternatively by bringing internet finance companies under the same set of rules). However, the latter option might decrease the financial efficiency and inclusion gains brought by technology as compliance costs will increase.

${ }^{76}$ In that respect, McKinsey \& Company expect that banks failing to digitize themselves face the possibility of having a $29 \%$ to $36 \%$ negative impact on their profits. Source:

<www.mckinsey.com/insights/financial_services/How_to prepare_for_Asias_digital_banking_boom>

${ }^{77}$ L. Shrader and E. Duflos, 'China: a New Paradigm in Brancheless Banking' (March 2014), CGAP, pp. 37 , 42.
} 
could leapfrog financial regulation standards by having its regulatory authorities establish a framework to promote and control the use of FinTech and internet finance companies. ${ }^{78}$

In many ways this is already happening at the industry level with developments in China now leading innovation in the financial sector, with new processes that are being replicated globally. For example Alipay's introduction of facial recognition payment in March $2015^{79}$ was followed by MasterCard in July $2015{ }^{80}$ Similarly SME lending by Alibaba in 2010 using alternative credit-scoring data from its e-commerce platform, was introduced in the US and Japan in 2012 and is now being undertaken by Amazon in Europe. ${ }^{81}$

These market developments echo the wider government objective of reforming the financial sector and promoting opportunities offered by digital financial services. The latest development was in July 2015 with the issuance of the Guidelines on the promotion of the healthy development of Internet Finance (hereinafter, The Internet Finance Guidelines) by ten ministries and commissioners. ${ }^{82}$

China's transition is both demand-driven and policy-driven. In addition, certain characteristics of the Chinese market make it particularly fertile ground for FinTech. World Bank statistics show how China differs when it comes to by whom and via what channels banking is delivered:

\begin{tabular}{|l|l|l|l|}
\hline & China & USA & UK \\
\hline Population without a Bank account in the last 12 months & 432 & 10 & 1
\end{tabular}

\footnotetext{
${ }^{78}$ See Weihuan Zhou, Douglas W. Arner and Ross P. Buckley "Regulation of Digital Financial Services in China: From last mover to first mover? (Sept 2015) available at <http://ssrn.com/abstract=2660050>; Douglas W. Arner and Janos Barberis "FinTech In China: From shadow banking to P2P lending", in Banking Beyond Banks \& Money" (Springer 2015 forthcoming) (illustrating how China went from innovation to duplication and the broader (inter)national consequences of this).

${ }^{79}$ See Geoffrey Smith, "Alibaba's Jack Ma shows off new 'pay with a selfie' technology" (17 March 2015) Fortune, available at <http://fortune.com/2015/03/17/alibabas-jack-ma-shows-off-new-pay-with-a-selfietechnology/>

${ }^{80}$ See Jose Pagliery, "Mastercard will approve purchases by scanning your face" (1 July 2015) CNN, available at <http://money.cnn.com/2015/07/01/technology/mastercard-facial-scan/>

${ }^{81}$ See Oliver Smith, "Looking for a UK Business loan? Amazon might be the answer" (29 June 2015) The Memo, available at <http://www.thememo.com/2015/06/29/looking-for-a-uk-business-loan-amazon-might-bethe-answer/>

${ }^{82}$ Guan Yu Cu Jin Hu Lian Wang Jin Rong Jian Kang Fa Zhan De Zhi Dao Yi Jian (Guideline on the Promotion of the Health Development of Internet Finance), promulgated on 18 July 2015. The Chinese official version of the Guideline is available at <http://www.mof.gov.cn/zhengwuxinxi/zhengcefabu/201507/t20150720_1332370.htm>
} 


\begin{tabular}{|l|l|l|l|}
\hline (nominal in million) & & & \\
Population without a Bank account (percentage) & $36 \%$ & $2.7 \%$ & $2.5 \%$ \\
Commercial Bank Branch per 100,000 people $^{83}$ & 7.7 & 35.2 & 24.2 \\
Bank ATM per 100,000 people $^{84}$ & 37.51 & 173.43 & 124.28 \\
\hline
\end{tabular}

Table 1: Banking Demographic and Delivery Channels

China has not had time to develop Western levels of physical banking infrastructure and the rise of FinTech means it probably never will need to do so. This is particularly so because technology is well developed in the country:

\begin{tabular}{|ll|}
\hline Number of SIM cards & 1,104 million \\
Percentage of mobile subscribers with 3G/4G access & $28.9 \%$ \\
Internet Users & 618 million \\
Online Banking penetration & $40.5 \%$ \\
\hline
\end{tabular}

The result of this mismatch between physical and digital infrastructure means the future for digital financial services in China is particularly bright. Already China UnionPay has, in under 15 years, become the world's largest payments provider. ${ }^{87}$

The lack of physical infrastructure and of customer expectations regarding banking constitutes an opportunity, which could see the development in China of a new paradigm in banking. The trend toward digital banking is already underway. Over the past three years in China, there have been 111 million new Internet banking customers, a 19\% increase in new personal bank accounts, and a $24 \%$ increase in online payments. ${ }^{88}$ In addition, it is expected that by 2020 there will be 900 million digital banking customers, compared to 380 million in 2012. ${ }^{89}$ Likewise, it is expected that by 2017 over 900 million Chinese will be credit scored

\footnotetext{
${ }^{83}$ See World Bank, data displayed for China, USA and UK are respectively from 2012, 2012 and 2011.

${ }^{84}$ See World Bank, data displayed for China, USA and UK are respectively date from 2012, 2009 and 2011.

${ }^{85}$ See World Bank, available at <http://data.worldbank.org/indicator/FB.CBK.BRCH.P5 >

${ }^{86}$ Compilation of data by authors original sources from Accenture 'Every Day Bank in China' (2015) and CGAP 'China: a New Paradigm in Branchless Banking' (March 2014).

${ }^{87}$ See The Nilson Report, "China UnionPay overtakes Visa to become the world's most used debit card" (10 April 2014) Finextra, available at <http://www.finextra.com/news/announcement.aspx?pressreleaseid=54849>

${ }^{88}$ See Accenture, 'Every Day Bank in China' (2015) page 3, available at <https://www.accenture.com/t20150714T065456 w /sk-en/_acnmedia/Accenture/ConversionAssets/DotCom/Documents/Global/PDF/Strategy 6/Accenture-The-Everyday-Bank-A-New-Vision-for-theDigital-Age.pdf>

${ }^{89}$ See Sonia Barquin and Vinayak HV, "Capitalizing on Asia's digital-banking boom" (March 2015) McKinsey, available at $\langle$ http://www.mckinsey.com/insights/financial_services/capitalizing_on_asias_digitalbanking boom>
} 
by the new credit bureau, Sesame Credit Management, part of Alibaba, using alternative data points. $^{90}$

Going forward, one should expect that the tension between traditional digital financial services and FinTech 3.0 providers will be greatest around the following three areas: (1) payments, (2) financing, and (3) deposits, with the last of these being the strongest contention point (and perhaps the main threshold for strong regulation). ${ }^{91}$

To support this digital financial transition, a framework must achieve various goals for each actor in the financial sector. Regulators must secure the necessary understanding and scope of operations to oversee the use of technology within the financial industry. Banks should compete equally in terms of regulatory burden with FinTech 3.0 companies which offer exact or close substitutes for regulated products. At the same time, start-ups need to operate within a regulatory framework that allows them to develop their business before becoming subject to expensive compliance costs.

Thus, the way forward may not necessarily lie in setting rules for financial products, but instead may lie in establishing threshold levels for when institutions need to comply with conduct rules for small actors, or prudential rules for larger players. This may avoid burdensome regulation with heavy compliance costs and limited benefits for financial stability. This would also help establish a boundary of operation between banks and internet finance companies and determine whether the distinction is based on products or transaction size.

\footnotetext{
${ }^{90}$ See Andrew Foxwell, “Asia loses out as FinTech start-ups head to the West” (2 June 2015) Asian Investor, available at <http://www.asianinvestor.net/News/397928, asia-loses-out-as-fintech-start-ups-head-to-thewest.aspx $>$. It is important to note that these individuals may have already been credit scored by traditional credit bureaus. However their true risk might have not been fully assesses due to the lack off sufficient data points (e.g. financial transactions perform within formal banking sector). These are called "thin credit files" by the industry and provide FinTech 3.0 companies large opportunities, the US and EU equivalent of Sesame Credit Management being Credit Karma and Kreditech.

${ }^{91}$ To date, deposit taking activities have not been approached by FinTech 3.0 start-ups. This reflects the fact that it is one of the most regulated activities within the financial services industry as it requires a banking licence. In turn this removes much of the economic rationale behind performing this function since the fact of holding deposits on its own generates little of no return. This would push start-ups to create two products from day one so as to up-sell products and services to make up for the cost generated by their deposit business.
} 
In this respect, it seems that China's current Internet Finance Guidelines and the consultation on third party payments which is due to be released before this year's end ${ }^{92}$ are pointing towards a two-tiered market, defined by transaction values. This is an imperfect solution as it caps the growth of internet finance providers, yet it may introduce a measure of regulatory harmony between traditional financial institutions (FinTech 2.0) and new start-up participants (FinTech 3.0).

Jack Ma, founder and CEO of Alibaba, rightly captured this difference when he said:

There are two big opportunities in future financial industry. One is online banking, all financial institutions go online; the other one is internet finance, which is purely led by outsiders. ${ }^{93}$

Regionally this is echoed in the development of tiered licensing systems in Asia, with governments in the region developing "light license" models that aim to minimize regulatory and compliance costs for firms seeking to deliver specific banking activities to certain population segments. For example, South Korea is developing a specific regime for onlineonly banks, ${ }^{94}$ India has created a new license type for payment banks ${ }^{95}$ and has recently issued 11 new banking licenses ${ }^{96}$ and China is introducing new private banks to cater for market sectors traditionally underserved by state-owned banks. ${ }^{97}$

These developments matter because they reflect the FinTech dynamic of the region and indicate a regulatory policy that favors the development of specific sub-sectors to promote national policy objectives.

\footnotetext{
${ }^{92}$ See Xinhua Finance, "China Headlines: New Regulation on third-party payments stirs controversy" (3 August 2015) Xinhua Finance, available at 〈http://en.xinfinance.com/html/Industries/Finance/2015/125158.shtml $>$

${ }_{93}$ See Lydia Guo, "Alibaba: shaking up Chinese Finance", (1 July 2013) Financial Times, accessible via <http://blogs.ft.com/beyond-brics/2013/07/01/alibaba-shaking-up-chinese-finance/>.

94 See Steven Deney "South Korea's Next Growth Frontier: FinTech" (13 August 2015) The Diplomat, available at $<$ http://thediplomat.com/2015/08/south-koreas-next-growth-frontier-fintech/>

${ }^{95}$ See IANS, "Some new banking licences by august, says Raghuram Rajan" (2 June 2015) The Times of India, available at $\langle$ http://timesofindia.indiatimes.com/business/india-business/Some-new-banking-licences-byAugust-says-Raghuram-Rajan/articleshow/47516988.cms>

${ }^{96}$ See Bernard Lunn, "11 new banking licences approved in India show the future of banking" (29 September 2015) Daily FinTech, available at <http://dailyfintech.com/2015/09/29/11-new-banking-licenses-approved-inindia-show-the-future-of-banking/>

${ }^{97}$ See Xinhua, "Mainland's $1^{\text {st }}$ private bank services niche markets" (27 March 2015) Shanghai Daily, available at $<$ http://www.shanghaidaily.com/business/finance/Mainlands-1st-private-bank-services-nichemarkets/shdaily.shtml $>$
} 


\subsection{Africa: Greenfield opportunities for FinTech}

Africa shares many characteristics with the APAC region in terms of FinTech development, however, the nature and direction of the primary developments in this area in Africa have been somewhat different. The reach of banks in Africa is even more circumscribed than in Asia. At most $20 \%$ of African households have any access to formal or semi-formal financial services as compared to some $60 \%$ of households in Asia. ${ }^{98}$ As a result, telecommunications companies, rather than banks, have tended to take the lead in FinTech developments in the region. Mobile money, the provision of basic payment and savings services by a creation of e-money recorded on a mobile phone, while initially pioneered in the Philippines has achieved its greatest success in Kenya and, more recently, Tanzania. In both of these countries the rise and extent of mobile money has assisted economic development significantly by providing customers with a means to save funds, remit money safely to their families, pay bills, and receive government payments safely and securely.

The most well-known success story in Africa is that of M-Pesa, the mobile money product of Safaricom, which was launched by Vodafone in 2007. In under five years payments made through the platform surpassed $43 \%$ of Kenya's GDP ${ }^{99}$ and the central bank is now having to supervise the provider carefully as the payments platform has become systemically significant.

Indeed the phenomenal success of M-Pesa has caused problems in many other countries, where companies offering mobile money services need to have as the screen saver on every corporate computer screen a prominent warning: "Be aware - we are not in Kenya" for many other countries have had to learn that merely replicating what was done in Kenya does not necessarily lead to similar customer take-up of digital financial services. For digital financial services (DFS) to prosper, the services offered have to be tightly tailored to local needs. ${ }^{100}$ Meeting the needs of the local consumers, whatever they may be, is the key requirement for success in providing DFS - and this is not the starting point for many of the people designing the DFS products coming, as they most often do, from an IT background.

\footnotetext{
${ }^{98}$ See KPMG, "Financial Services in Africa" (2013) p. 4 available at $<$ https://www.kpmg.com/Africa/en/IssuesAndInsights/ArticlesPublications/Documents/KPMG\%20Financial\%20Services\%20in\%20Africa.pdf>

${ }^{99}$ See, Daniel Runde, "M-Pesa and the rise of the Global Mobile Money Market" (12 August 2015) Forbes, available at <http://www.forbes.com/sites/danielrunde/2015/08/12/m-pesa-and-the-rise-of-the-global-mobilemoney-market/>

${ }^{100}$ See, Gabriella Mulligan, “Can M-Pesa travel outside Kenya?” (2 December 2014) African Business, available at $<$ http://africanbusinessmagazine.com/sectors/technology/can-m-pesa-travel-outside-kenya/>
} 
Nonetheless, Africa's FinTech journey to date has mostly consisted of the provision of mobile money services permitting the core functions of payments and savings, and relatively recently the higher order services of credit and micro-insurance.

The typical African provider of DFS is a telecommunications company that encourages customers to purchase e-money, as well as airtime, on their mobile phone; and usually in the same way and at the same place as buying airtime (i.e. by paying cash to a retail agent), who is typically a small shopkeeper who sells e-money and airtime, along with soft drinks, snacks and the like. This profile is rather similar to mobile money developments in some Asian nations, such as Cambodia, Laos, and others, but dramatically different to the profile of DFS in China, or India. With that said it is expected to see an increase amount of South-South technology transfers within FinTech. ${ }^{101}$

\section{Regulatory Innovation and the Importance of RegTech}

This paper has illustrated the application of technology to finance and its consequences over three major eras of FinTech. The main divergence witnessed today is between FinTech 2.0 and FinTech 3.0, particularly in the type of entity that uses the technology to deliver a financial product or service. FinTech is no longer the preserve of traditional financial institutions.

A visual illustration of this is provided in the table below, as each of these names are regarded as FinTech companies in their own right:

\begin{tabular}{|c|c|c|c|}
\hline \multirow[b]{2}{*}{ Rank } & \multicolumn{2}{|c|}{ FinTech 2.0} & FinTech 3.0 \\
\hline & $\frac{\underline{\text { Banks }}}{\text { by market cap }(2015)}$ & $\begin{array}{l}\text { IT Companies } \\
\text { by revenue (2014) }\end{array}$ & $\frac{\text { Start-ups }}{\text { by valuation }(2015)}$ \\
\hline $1^{\mathrm{st}}$ & Wells Fargo \& Co (US) & FIS (US) & $\operatorname{LuFax}(\mathrm{CN})$ \\
\hline $2^{\text {nd }}$ & $\operatorname{ICBC}(\mathrm{CN})$ & Tata (IN) & Square (US) \\
\hline $3^{\text {rd }}$ & JP Morgan (US) & Fiserv (US) & Markit (US) \\
\hline
\end{tabular}

${ }^{101}$ See Gulveen Aulakh "Alibaba, Ant Financial invest about $\$ 680$ million in Paytm, up stake to $40 \%$ " The Economic Times, available at

$\langle$ http://economictimes.indiatimes.com/industry/banking/finance/banking/alibaba-ant-financial-invest-about680-million-in-paytm-up-stake-to-40/articleshow/49148651.cms> 


\begin{tabular}{|l|l|l|l|}
\hline $4^{\text {th }}$ & CCB (CN) & Cognizant (US) & Stripe (US) \\
\hline $5^{\text {th }}$ & Bank of America (US) & NCR Corp (US) & Lending Club (US) \\
\hline $6^{\text {th }}$ & Bank of China (CN) & Infosys (IN) & Zenefits (US) \\
\hline $7^{\text {th }}$ & ABC (CN) & Diebold (US) & Credit Karma (US) \\
\hline $8^{\text {th }}$ & Citi Group (US) & Sungard (US) & Powa (UK) \\
\hline $9^{\text {th }}$ & HSBC (UK) & Nomura (JP) & Klarna (SWE) \\
\hline $10^{\text {th }}$ & Mitsubishi (JP) & CA Tech (US) & CommonBond (US) \\
\hline
\end{tabular}

Table 3: Ranking of FinTech 2.0 and 3.0

Compiled by the authors ${ }^{102}$

On the one hand, as explained in sections 2 and 3, financial institutions' transition towards digitizing their processes and services is a well-understood market trend with defined regulatory implications and obligations related to the use of technology. Established financial actors, technology companies and regulators work with each other. On the other hand, new technology players (FinTech 3.0) are entering the financial industry with limited or no preexisting interaction with financial regulators. These businesses tend to lack a financial compliance culture that identifies providers' prudential or consumer protection obligations when delivering financial services. ${ }^{103}$

As a result, the non-traditional business models or financial products offered by FinTech 3.0 companies may not comply with applicable financial regulations. This lack of regulatory compliance may be active as when a technology company does not believe it should be subject to rules and regulations meant for banks, or passive as when a technology company is not aware of the rules and regulations that may apply.

This is precisely where the current debate and discussion around FinTech regulation lies. Right now there is uncertainty as to what laws and procedures are applicable to new FinTech

\footnotetext{
102 Sources: "World's Largest Banks 2015" available at $<$ http://www.relbanks.com/worlds-top-banks/marketcap> and "Top 100 Companies in FinTech" (12 Nov 2014) The American Banker, available at <http://www.americanbanker.com/news/bank-technology/top-100-companies-in-fintech-1071192-1.html> and Oscar Williams-Grut, "The 25 FinTech 'Unicorns' worth over \$1billion ranked by value" (21 August 2015) Business Insider, available at <http://uk.businessinsider.com/the-25-fintech-unicorns-ranked-by-value-20157 ? utm content=buffer05d0a\&utm $\_$medium=social\&utm_source=twitter.com\&utm_campaign=buffer $>$

${ }^{103}$ The counterargument is that if FinTech start-ups are created by ex-finance professionals they should understand regulated markets with compliance cultures. This is highlighted by looking at where FinTech companies are founded. Start-ups close to financial centers such as New York, London or Hong Kong tend to have stronger compliance cultures than those in other locations such as Silicon Valley where the founders are more likely to be engineers than finance professionals.
} 
solutions. The solution is to be found in devising an approach that balances the views of each party (e.g. the technology industry, financial actors and regulators) and is proportionate to their obligations. Performing this balancing act requires one to understand the raison d'etre of regulators and the reasons behind the rules they enforce and to provide education for for start-ups on their regulatory obligations.

\subsection{Regulatory objectives and thresholds}

Regulators' objectives can be understood by their key mandates. In no specific order, these are: (1) financial stability, (2) prudential Regulation, (3) conduct and fairness, and (4) competition and market development. Furthermore the issue of when to regulate can be as important as what to regulate, so that some rules may not be enforced until certain specific thresholds are met. This was seen in Section 2.2.1 in the regulation of e-banking which existed for about 20 years before it was properly regulated.

Earlier regulation may well have represented substantial wasted effort. E-banking was introduced in 1980 in the US but stopped shortly thereafter, before being reinstated successfully in 1995 in the UK. E-banking is a good example of why regulators should move slowly in regulating innovations. Regulators diverting their resources to understand every new technological innovation could result in inefficient outcomes for regulators and industry.

First, technology needs time to find its final use and applicability, and the market may need to settle before regulatory intervention. ${ }^{104}$ Second, the availability alone of a technology does not mean it will be widely adopted. ${ }^{105}$ Third, there may be a strong benefit in regulatory measures not influencing market innovation or technological standards. Indeed, regulators should remain technology-neutral.

In practice, this means regulators need to categorize and understand the benefits and applicability of a technology. For example, new biometric identification mechanisms entering

\footnotetext{
${ }^{104}$ Going forward regulators should not rely on technological adoption lag. Indeed, Rita McGrath, in "The Pace of Technology Adoption is speeding up" (25 November 2013) points out that "It took decades for the telephone to reach $50 \%$ of households, beginning before 1900. It took five years or less for cell phones to accomplish the same penetration in 1990". This is even clearer in places such as China.

${ }^{105}$ On that note, the example of the blockchain technology illustrates this point as it still lacks an example of consumer facing solutions adopted by the public. The laser was similar, in that it was a "solution in search for a problem" for decades before it was widely used in multiple industries. See chapter 14 of Mario Bertolotti, "The History of Laser" (2004) CRC press.
} 
the market (e.g. fingerprint and iris scanning, voice or heartbeat recognition) raise different case-specific issues, but are all used for the same purpose of customer identification.

Finger print scanning appears to be the simplest and most widely used biometric identification method. However, it raises issues of "biometric data theft" where a fingerprint can be replicated using a simple high resolution photograph. ${ }^{106}$ This risk recently materialized, when 5.6 million finger prints were stolen from the US defense department. ${ }^{107}$ A case can thus be made against using fingerprints due to the security risk. ${ }^{108}$

However, the decision to allow or ban a technology is perhaps best not left to regulators because until a specific technology becomes widely used, risks of biometric data-theft and un-authorized transactions are limited. Instead, in most instances, regulators should remain technologically neutral and focus on the outcome of a technology. ${ }^{109}$ A wait-and-see approach allows the regulator to learn whether the market will adopt the technology, and draw on historical data as to the risks a specific technology creates.

This efficiency analysis of regulators' time, given their constrained resources, highlights the benefits of supervising and regulating only a limited number of large players. In FinTech 2.0, technological innovations were generally developed by actors with an established compliance culture and thus it was seen as more efficient to let a market self-regulate until it became worthy of regulators' time. ${ }^{110}$ Whilst the innovations themselves were new, the actors deploying them were not (e.g. Barclays' ATM, Bank of America's credit card, investment bank VAR models), and thus regulators could take comfort from knowing they had a point of contact for when they decided to look at the legal implications of specific technologies.

\footnotetext{
${ }^{106}$ See Alex Hern, "Hacker fakes German minister's fingerprints using photos of her hand" (30 December 2014) the Guardian, available at <http://www.theguardian.com/technology/2014/dec/30/hacker-fakes-germanministers-fingerprints-using-photos-of-her-hands $>$

107 See David Alexander, "5.6 million fingerprints stolen in U.S. personnel data hack: government" (23 September 2015) Reuters, available at <http://www.reuters.com/article/2015/09/23/us-usa-cybersecurityfingerprints-idUSKCN0RN1V820150923>

${ }^{108}$ This raises an important questions and potential risks in the context of China. Indeed the data privacy regime being less strict allows private companies to store and share biometric data in ways that would be prohibited in Europe or the US. Thus there is a potential cybersecurity risk of having private companies losing the biometric data of their consumers following an attachment, especially if these are used an identification token for financial transactions (e.g. finger prints to authorise payments).

${ }^{109}$ However, this is not the case of all regulators, as discussed with the Singaporean example.

${ }^{110}$ This is not to say that actors within the financial sector have a flawless track record of compliance, as was shown with the various fraud cases emerging out of the 2008 financial crisis.
} 
This approach can be cost-effective for regulators, and industry, as it experiment with initiatives until they become sufficiently important to attract regulatory scrutiny.

From an industry and regulatory perspective, the pharmaceutical industry perhaps offers a blueprint for regulating innovation. This industry is, similarly to financial services, highly regulated. Breakthroughs are allowed via a clear and gradual path of clinical trials and authorizations. Large groups are increasingly outsourcing this R\&D stage of the process by acquiring the start-ups and university spin-offs which are developing the new drugs.

Parallels arise with the financial industry, albeit in a less coordinated manner. FinTech 3.0 innovations are emerging out of sand-boxes, incubators or accelerator programs where startups refine their solutions. Graduating from these accelerators flags that the company has to some extent matured given its participation in a structured curriculum. Banks then partner with, invest in, or acquire these companies.

There are also benefits for regulators, as their previous method, whereby they only look at established financial institutions that start to deploy products or services on a significant scale, is challenged under the FinTech 3.0 model. Whilst pre-2007, regulators could take some comfort that regulated financial institutions with which they already had a relationship would handle innovations responsibly, this is no longer necessarily the case.

Money market funds (MMF) offer an example. Three of the largest players in this sector (Vanguard, Fidelity and Schwab) were established in 1975, 1946 and 1971 respectively. In 2014 an e-commerce business in China, Alibaba, started to offer a new MMF that is fully online and available to its pre-existing customer base. Within nine months, Yu'E Bao became the world's $4^{\text {th }}$ largest MMF, on par with decade-old players such as Vanguard or Fidelity. ${ }^{111}$

Yu'E Bao shows how a non-traditional financial institution went from "too-small-to-care" to "too-big-to-fail"112 within the space of nine months. This exponential growth represents a direct challenge to the otherwise more gradual approach towards regulating innovations and

\footnotetext{
${ }^{111}$ See Bill Powel,“Alibaba the $\$ 200$ billion Open Sesame” (8 September 2014) News Week, available at <http://www.newsweek.com/2014/09/19/alibaba-200-billion-open-sesame-268937.html>

112 The concept of "too-small-to-care to "too-big-to-fail" was initially developed by Douglas W. Arner, Janos Barberis, "Regulation of FinTech Innovation: A Balancing Act" (1 April 2015) AIIFL, available at $<$ http://www.law.hku.hk/aiifl/regulating-fintech-innovation-a-balancing-act-1-april-1230-130-pm/
} 
stakeholders, skipping the "too-large-to-ignore" phase when regulators would have started to contact and request compliance of the said entity ${ }^{113}$

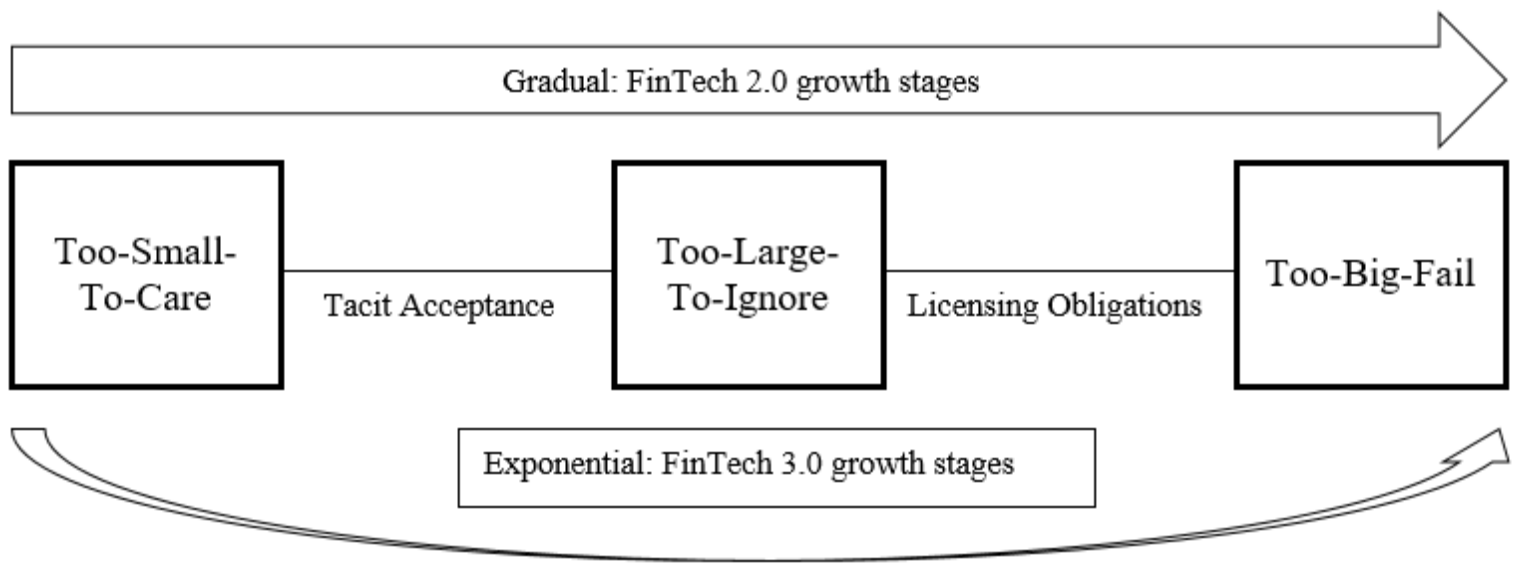

Figure 2: Regulatory threshold approaches compared to growth models Source: Arner and Barberis: "FinTech Regulation Recent Developments and Outlook (1 April 2015) AIIFL

In other words, if primarily regulating actors with a significant impact on financial markets remains the correct approach, which we submit is the case, what needs to change in extraordinary cases may be the methods used to identify in time the future systemically important actors. ${ }^{114}$

Given the size of investment and the competitive implications stemming from the arrival of these new players in the financial services industry, regulators in various jurisdictions also need to review the best approaches to support FinTech and adjust their methods (e.g. rule or principle-based) towards regulation. ${ }^{115}$

\footnotetext{
${ }^{113}$ Following the fingerprint example, one can also use the fact that Apple sold over 10 million iPhone 6, which were all pre-loaded with a mobile wallet and finger print scanner to identify transactions, See Press Release, "First Weekend IPhone sales top 10million, set new record" (22 September 2014) Apple, available via $<$ http://www.apple.com/pr/library/2014/09/22First-Weekend-iPhone-Sales-Top-10-Million-Set-NewRecord.html>

${ }^{114}$ It is accepted that not all companies will become too-big-to-fail and reach the scale of Yu'E Bao but most have the aspiration of being billion dollar company. Furthermore in an ever interconnected financial system market size and systemic risk are not necessarily correlated. The Dow Jones flash crash in May 2010 illustrate that smaller players can also become systemic.

${ }^{115}$ The advantages and disadvantages of each method are well covered in Chris Brummer and Daniel Gorfine "FinTech: Building a $21^{\text {st }}$ Century Regulator's Toolkit" (2014) Milken Institute, available via $\langle$ http://assets1c.milkeninstitute.org/assets/Publication/Viewpoint/PDF/3.14-FinTech-Reg-Toolkit-NEW.pdf〉
} 


\subsection{Adapting regulatory methods in a digital age}

From an industry perspective and from a regulatory perspective alike, an attitude change is needed towards how FinTech products and services should be regulated. However, as pointed out above, there is currently difficulty in accurately representing the hardship faced by the industry as a whole, since it is comprised of established players (bankers, FinTech 2.0) and emerging players (start-ups, FinTech 3.0).

This creates two sets of distinct expectations and needs in respect to how industry players' activity should be supervised. From a start-up perspective, the high cost of regulation (e.g. due to compliance, license applications, etc.) is incompatible with their lean business model. At an early stage start-ups need to defer expenses as much as possible to focus on building a viable product with business potential. The group of early-stage companies that emerged during FinTech 3.0 prefers the more flexible compliance obligations of a principle-based regulatory regime. Under this regulatory approach, more focus is given to the spirit of a regulation rather than "box ticking". This seems to be the route taken in the UK. Private parties subject to this regime may have a certain degree of discretion in implementing the regulation.

Principle-based regulatory regimes differ from rule-based regimes. The latter create clear rules and processes. From a start-up perspective, this approach is expensive as each rule and process needs to be identified and complied with, ${ }^{116}$ which may significantly consume financial resources of a start-up that could instead be used to build the business.

The benefits of principle and rule-based approaches are however not clear from the perspective of start-ups and large financial institutions. The flexibility of a principle-based

model creates a level of uncertainty as to what exactly is expected in terms of compliance. ${ }^{117}$ As for the rule-based approach, the fact that the compliance obligations are clearly set out can limit the incentive of the supervised entity to do more because the obligations are perceived as sufficiently comprehensive.

\footnotetext{
${ }^{116}$ Ibid. p. 7.

${ }^{117}$ Ibid.
} 
There is nonetheless a way of resolving the differences between not only principle and rulebased regulatory approaches, but also between traditional financial institutions (FinTech 2.0) and start-ups (FinTech 3.0). The solution may lie in going beyond a strict reading of the text so that regulatory approaches, whether rule-based or principle-based, are not seen as mutually exclusive.

For example, whilst a principle-based approach may provide a start-up with the benefit of flexibility at an early stage, this may create limitations in terms of scalability of a business. Regulatory clarity and certainty are not only important for large institutions but also for investors into start-ups. ${ }^{118}$ For start-ups, the legal predictability and higher compliance costs associated with a rule-based model may be balanced by being more attractive to investors. Then, as the start-up matures, so does its compliance culture and capacity as it has increasing access to sufficient financial resources. The higher costs and complexity associated with a rule-based approached can thus be understood as a benefit, both for the company and the investor. Indeed, rules-based regulatory approaches are more likely to create a barrier to entry for subsequent new competitors. ${ }^{119}$

The regulatory obligations of a company should be dynamic in the sense they need to adapt to the size and activity of a business as it grows and changes. ${ }^{120}$ The P2P industry offers a case study. Many businesses start as a platform as agents introducing lenders to borrowers and are not involved in the loan itself. This is important for P2P debt FinTech 3.0 start-ups because it means they may have limited regulatory obligations. However, this operational model also limits their capacity to scale as it relies on always being able to match the exact needs of a borrower with the liquidity of a lender. From a risk angle, the matching also exposes the lender to the direct credit risk of the borrower. Since the platform is only an agent as opposed to a principal, it is not responsible for any losses resulting from a partial or complete default.

\footnotetext{
118 FCA, "Project Innovate: Call for Input Feedback Statement" (October 2014) available at <https://www.fca.org.uk/static/documents/feedback-statements/fs-14-2.pdf>

$11 \overline{9}$ See Julia Groves, "Crowdfunding - Regulations are now the biggest barrier to entry" (30 May 2014) UK Crowdfunding, available <http://www.ukcfa.org.uk/crowdfunding-regulations-are-now-the-biggest-barrier-toentry/news>

${ }^{120}$ For more detail on real-time regulation, see Tim O’Reilly, "Open Data and Algorithmic regulation" in Beyond Transparency: Open data and the future of civic education (2013) Code for America press.
} 
This shifting of risk towards the lender has two consequences. First, if an increasing amount of lender(s) lose their capital as a result of a badly evaluated credit risk, their confidence in the platform will fall and they will not likely re-use it. ${ }^{121}$ Second, the risk profile of such a liquidity placement on a P2P platform is much higher given that the risk is directly passed on to the lender. As a result, this limits the number of potential lenders since the increase in return is accompanied by an increase in risk.

Therefore, for P2P lending platforms to maintain user confidence and attract a wider lender base, it may well be necessary to move away from a purely agent-based model and instead come principal-based model. ${ }^{122}$ Alternatively, the platform may wish to spread the credit risk of the borrower by originating a loan using the liquidity of various lenders. This limits the credit risk of each lender to its chosen contribution. Additionally, the ease (e.g. convenience and speed) of borrowing over P2P platforms and the lack of co-ordination among platforms is creating a risk of over indebtedness among borrowers. ${ }^{123}$

The P2P sector offers a good example of how regulation needs to proceed carefully when creating rules for an industry. ${ }^{124}$ Industry demands may represent nothing more than a snapshot in time of their difficulties and may fail to address the evolving nature of their business as it grows in terms of market size and risk.

FinTech 3.0 thus needs a framework that is both balanced and dynamic, benefiting simultaneously private stakeholders (e.g. institutional or start-ups) and regulators.

\footnotetext{
${ }^{121}$ In China, over 1250 platforms have been flagged "at risk" by the local credit rating agency Dagong. See Judy Chen and Jun Luo, "Internet Loan Alarms Dagong with 1'250 red flags (13 March 2015) Bloomberg, available at $\quad$ http://www.bloomberg.com/news/articles/2015-03-12/internet-loan-alarms-dagong-with-1-250-red-flagschina-credits $>$

${ }^{122}$ There have been reports that in order to maintain confidence in $\mathrm{P} 2 \mathrm{P}$ platforms in China, the platform owners would pay any incurred default to the lenders. Whilst this is something that can be done if the platform is cash rich, given health interest spread they retain, it can also be a hint towards the start of a Ponzi scheme challenging the ultimate viability and raises problems of fraud. See Wang Shenlu, Liu Ran and Yang Lu "P2P lenders heading into Dangerous Waters, critics say" (18 April 2014) Caixin, available at <http://english.caixin.com/2014-04-18/100667283.html>

${ }^{123}$ See Michael Corkery "Pitfalls for unwary borrower out on the frontier of Banking" (13 Sept 2015) The New York Times, available at <http://www.nytimes.com/2015/09/14/business/dealbook/pitfalls-for-the-unwaryborrower-out-on-the-frontiers-of-banking.html? $\mathrm{r}=0\rangle$

${ }^{124}$ In that context, the US is still waiting for majors amendments to the JOBS Act, which depending on the outcome may facilitate the growth of equity crowd-funding platform. However and until then PE investors are not investing in these platforms until they receive regulatory certainty as to the compliance status of their future platform. Thus regulation can similarly be seen as a technology that allows businesses to scale, or not.
} 


\subsection{A case for the development of RegTech}

While previous sections considered the evolution of FinTech and its challenges for traditional regulation, this section turns to the application of technology to regulation itself: Regulation Technology (RegTech). The relevance of discussing RegTech echoes the fact that, with the increased use of technology within the financial services industry, regulatory bodies have the opportunity to access a level of granularity in risk assessments that did not previously exist. Indeed, Andy Haldane, Chief Economist of the Bank of England, when discussing the future of regulation shared his vision:

What more might be feasible? I have a dream. It is futuristic, but realistic. It involves a Star Trek chair and a bank of monitors. It would involve tracking the global flow of funds in close to real time (from a Star Trek chair using a bank of monitors), in much the same way as happens with global weather systems and global internet traffic. Its centre piece would be a global map of financial flows, charting spill-overs and correlations ${ }^{125}$

This vision of a data-led regulatory system is not new. Since 2007 there has been increased focus on this from regulators, industry and academia. In 2009 the SEC created the division for Economic and Risk Analysis, to look at using data insights for better regulation; and Peppet published a paper on "smart mortgages" that use data to limit the default risks. ${ }^{126}$ However, one needs to balance the opportunities presented by technology with practical barriers to actual and successful implementation, which are discussed below.

Regulatory interest in the FinTech sector represents a turning point. No longer are regulators solely seeking to prevent the previous crisis and instead are looking at how to support future market developments whilst maintaining financial stability. There are benefits for a regulator from early interaction with new FinTech start-ups, even if they are not yet significant or able to (currently) comply with the rules. This provides regulators the capacity to understand from early-on the business models of FinTech 3.0 start-ups, and the teams behind them (so as to see whether they are fit and proper for that role). This has been the approach in various jurisdictions. For example, the UK's Financial Conduct Authority (FCA) not only initiated a

\footnotetext{
${ }^{125}$ Andrew G Haldane, "Managing global finance as a sytem" (29 October 2014) Bank of England, available at $\langle$ http://www.bankofengland.co.uk/publications/Documents/speeches/2014/speech772.pdf>

${ }^{126}$ Peppet, Scott R., "Smart Mortgages, Privacy and the Regulatory Possibility of Infomediation". U of Colorado Law Legal Studies Research Paper No. 09-13. Available at 〈http://ssrn.com/abstract=1458064〉
} 
consultation to understand the regulatory hurdles faced by FinTech 3.0 companies, ${ }^{127}$ but also complemented it with an innovation hub to interact with and support innovative start-ups from a nascent stage. ${ }^{128}$

This awareness phase is also seen in Asia. The Securities and Futures Commission of Hong Kong is part of the Hong Kong government's FinTech Steering Group ${ }^{129}$, AISIC in Australia has open hours in a co-working space ${ }^{130}$, the Monetary Authority of Singapore has made SG\$ 225 million investment in research, ${ }^{131}$ whilst southeast Asian countries have implemented new rules on alternative finance (debt or equity), with Malaysia being the first ASEAN country to have crowdfunding laws. ${ }^{132}$

The effort and resources regulators are putting into understanding the FinTech sector is perhaps surprising, particularly as they are to some extent revisiting the same questions and risks identified over 15 years ago with e-banking. Furthermore, apart from specific products (e.g. robo-advisory), the business models of FinTech companies are not radically different from their traditional counterparts (e.g. P2P lending emanating from shadow banking in China). ${ }^{133}$ At most, the efficiency is driven by lower overhead costs, or disintermediation. To some extent FinTech is going full circle and providing only incremental changes, both from industry and regulatory perspectives.

\subsection{Real-time compliance and RegTech}

As discussed above, the financial sector has been the largest spender on IT systems for decades, a trend likely to continue, especially in respect to regulatory and compliance

\footnotetext{
127 See FCA, "Project Innovate: Call for Input - Feedback statement" (October 2014) FCA, available at <https://www.fca.org.uk/static/documents/feedback-statements/fs-14-2.pdf>

128 See Martin Wheatley, "Innovation: The Regulatory Opportunity" (28 October 2014) FCA, available at $<$ http://www.fca.org.uk/news/innovation-the-regulatory-opportunity>

129 See Press Release, "Steering Group on FinTech Established" (30 March 2015) available at <http://www.info.gov.hk/gia/general/201503/30/P201503300535.htm>

${ }^{130}$ See Michael Saadat, "Facilitating Innovative FinTech Businesses' - A regulator's perspective” (29 April 2015) Criterion Conferences, available at <https://www.criterionconferences.com/blog/socialtech/facilitatinginnovative-fintech-businesses-regulators-perspective/ $>$

131 See Ravi Menon, "Keynote Address: A Smart Financial Centre" (29 Jun 2015) MAS, available at <http://www.mas.gov.sg/news-and-publications/speeches-and-monetary-policy-statements/speeches/2015/asmart-financial-centre.aspx $>$

${ }_{132}$ See JD Alois, "Malaysia is first ASEAN country with crowdfunding laws" (1 July 2015) Crowd Fund Insider, available at <http://www.crowdfundinsider.com/2015/07/70514-malaysia-is-first-asean-country-withcrowdfunding-laws/>

${ }^{133}$ See Douglas W. Arner and Janos Barberis, "FinTech in China: From Shadow Banking to P2P Lending" (Springer 2015 Forthcoming)
} 
spending. In the wake of the 2008 Global Financial Crisis, the regulatory onus and level of scrutiny by regulators has dramatically increased. Indeed, regulators have moved towards a risk-based approach where access to data is key to prudential supervision. Gutierez has analyzed how data is playing an increasing role in ensuring financial institutions are held accountable for their actions, and their responsibility is quickly established. ${ }^{134}$ This appears to be a laudable development. ${ }^{135}$

For financial institutions all of this regulatory activity has meant cost increases, whether in terms of capital (e.g. Basel 3), operations (e.g. human resources), or penalties (e.g. HSBC, UBS, etc.). On the last point alone, since 2008, banks in the west have been fined over US\$242 billion. ${ }^{136}$ Arguably, both industry and regulators share an interest in reducing fraud. A range of stakeholders are interested in increasing transparency and creating monitoring processes. In June 2015 the Bank of England issued its Fair and Effective market review, looking at the role that technology may play in compliance, ${ }^{137}$ noting that:

Firms have started to make progress in response to the limitations of existing surveillance solutions, including the use of new technology and analytics which go beyond the key-word surveillance and simple statistical checks previously used by firms to detect improper trading activity and discussed earlier in this section. ${ }^{138}$

In particular, the Bank of England highlighted the following added values for regulation of specific technologies: 139

- Pattern analysis which can be used to identify unusual patterns of activity, such as "spoofing" (placing an order and then cancelling it seconds later to encourage others

\footnotetext{
134 Daniel Gutierrz "Big Data for Finance - Security and Regulatory compliance considerations" (20 Oct 2014) Inside Big Data, available at <http://insidebigdata.com/2014/10/20/big-data-finance-security-regulatorycompliance-considerations/ $>$

${ }^{135}$ Data transparency allows regulatory bodies to supervise firms without having to ask for specific reports (e.g. stress tests on liquidity and capital). Direct data access therefore prevents the regulated subject to change its behavior and data in reaction to the asked questions.

${ }^{136}$ Micahel Mainelli, "RegTech - worthy of Investment" (24 June 2015) IGTB, available at 〈http://igtb.com/article/regtech-\%E2\%80\%93-worthy-investment>

${ }^{137}$ Charles Roxburgh, Minouche Shafik and Martin Wheatley, "Fair and Effective Market Review: Final Report" (June 2015) Bank of England, available at $\langle$ http://www.bankofengland.co.uk/markets/Documents/femrjun15.pdf>

${ }^{138}$ Charles Roxburgh, Minouche Shafik and Martin Wheatley, "Fair and Effective Market Review: Final Report" (June 2015), page 90 available at 〈http://www.bankofengland.co.uk/markets/Documents/femrjun15.pdf>

${ }^{139}$ Ibid. p. 91.
} 
to drive up the price of a particular asset), front running and wash trades, using predefined patterns of trading behaviour;

- "Big data" techniques, which typically use a far larger number of inputs than standard surveillance techniques, helping to straddle information silos. The algorithms used have the potential to detect a wider range of suspicious activity than pattern analysis, and can also be used to identify networks of trading and communications activity which may themselves identify vulnerabilities;

- Predictive coding, which looks to identify patterns of activity, such as unusual use of communication, non-routine patterns of leaving the office, non-completion of training, or missing mandatory leave, which may flag potential conduct concerns, and

- Digitalization of voice communications, which some firms claim has the potential to be more effective than analysing written communications.

As a result, the argument for cost reduction within the compliance sector is very strong, and RegTech has never looked so beneficial for firms. Yet, one also needs to be balanced in assessing what is currently feasible when it comes to fully automating regulatory and compliance systems. ${ }^{140}$

Before looking at the conversion of compliance obligations into IT processes the first question is more fundamental - how should financial technology itself be regulated? ${ }^{141}$ To date the debate, especially in Asia, seems to be more on understanding what framework provides the right balance between market innovation and market confidence. ${ }^{142}$

Furthermore, whilst in the West RegTech has been developed much more by regulators (the UK government dedicated a chapter of the Blackett Review ${ }^{143}$ to the topic and Europe is pushing towards increased data transparency with PSD2) in practice there are still

\footnotetext{
${ }^{140}$ Vytautas Cyras and Reinhard Riedl, "Formulating the enterprise Architecture compliance problem" (2009) available at $\langle$ http://ceur-ws.org/Vol-924/paper14.pdf. $>$

${ }^{141}$ See section 6.2 .

142 "Some Chinese are take 22\% margin loans to finance sock purchases" (1 July 2015) Blomberg available at <http://www.bloomberg.com/news/articles/2015-06-30/hidden-china-stock-debt-revealed-in-online-loans-at-22interest>

143 Government Office for Science, "FinTech: Blackett Review" (18 March 2015) available at https://www.gov.uk/government/publications/fintech-blackett-review
} 
uncertainties, as reported by Brummer and Gorfine, as to whether or not principle-based approaches are better suited than rule-based approaches. ${ }^{144}$

To understand regulator's activity, one needs to look at two factors. First, at the macro level their interest reflects the need to guide the transition occurring in financial markets. Just as an abrupt transition towards liberalized financial markets can be detrimental for participants and consumers, so can a fast technological transition create new risks. For example, the simplification and automation of wealth management services into color-coded advisers, ${ }^{145}$ provides a simpler and cheaper solution for end-users. However, this also creates new risks as it moves away from a full disclosure regime and threatens jobs within the industry.

At the micro level, the increasingly data-driven aspects of FinTech 3.0 and the fact that these young companies rely on new and transparent IT systems allows them to explore new compliance mechanisms. ${ }^{146}$ For example, real-time compliance systems could be requested as part of the licensing process. This would provide regulators and the company with a way to monitor in quasi-real time the actions of its staff and identify any non-compliant behaviour. In that scenario the firm wins because it limits its risk of misconduct and so does the regulator with better regulatory outcomes. ${ }^{147}$

From a market perspective, the capacity to analyze in real time the solvency, liquidity and risk of a financial institution promotes both market stability and competition. Regulatory models where data is traded-off with regulatory capital could provide a more appropriate cost of market entry for new companies. Their level of regulatory capital and scrutiny could then gradually increase as their business growth as opposed to fall under the current blanket licensing system. ${ }^{148}$

\footnotetext{
${ }^{144}$ Chris Brummer and Daniel Gorfine, "FinTech: Building a $21^{\text {st }}$ Century Regulator's Toolkit" (October 2014) Milken Institute, p. 8, available at <http://assets1b.milkeninstitute.org/assets/Publication/Viewpoint/PDF/3.14-FinTech-Reg-Toolkit-NEW.pdf>

${ }^{145}$ For example, a "green portfolio" would be properly balanced to the risk appetite of the user but gives no exact details as to the content of the portfolio itself (and its re-adjustment in the future). This simplification feels to be at the other side of the spectrum to the full disclosure regime that creates information overload to the client buying a financial product.

${ }^{146}$ See Douglas Arner and Janos Barberis, "FinTech in China: From Shadow Banking to P2P Lending (2015)

${ }^{147}$ More broadly, this refers to the wider theme of Regulation Technology or "RegTech." For more details see the short introductory chapter by the Government Office for Science, "FinTech: Blackett Review: (March 2015) available at 〈https://www.gov.uk/government/publications/fintech-blackett-review >

${ }^{148}$ In the UK there is a new regime for challenger banks to obtain a licence for the PRA and FCA. If a new entrant qualifies as a Small Specialist Bank, the minimum capital required is GBP 1.2 million as well as any cost to wind down the bank. This is a much lower threshold which sets a level of capital proportionate to the actual loan book and risk of the Bank. For more details about entry requirements and developments within the
} 


\section{Conclusion}

This paper has illustrated the evolution of FinTech through three major eras, culminating in today's FinTech 3.0, characterized by new competition and diversity, bringing both opportunities and risks to be carefully considered.

In developed markets, this shift to FinTech 3.0 has emerged out of the Global Financial Crisis of 2008 and been driven by public expectations and demands, the movement of technology companies into the financial world and political demands for a more diversified banking system. In contrast, in developing countries and particularly Asia, FinTech 3.5 has been driven by the needs of development and the inefficiencies in the existing financial system, combined with the rapid introduction and reach of new technology, particularly mobile communications.

In both cases, the development of the FinTech sector is attracting the interest of regulators who are currently evaluating the best ways to support market developments, while ensuring the development of the sector contributes to, and does not threaten, core mandates such as systemic stability, consumer protection and market competition The challenge lies in resolving the tension between having a flexible, forward-looking framework that promotes innovation, and the framework being clear enough to maintain market, consumer and investor confidence.

There seem to be two approaches in that respect. On the one hand, the UK in the wake of the Global Financial Crisis has changed its regulatory structure, moving away from a productbased to a principle-based approach, focusing on prudential regulation and consumer protection. China, on the other hand, has maintained product-based principles but is gradually introducing a two-tiered system where small to medium transactions can be handled by internet finance companies, while larger transactions remain in the remit of (State-owned) institutional players.

challenger banking space in the UK, see Bank of England, "A review of requirements for firms entering into or expanding in the banking sector: one year on" (July 2014) Bank of England available at <http://www.bankofengland.co.uk/pra/Documents/publications/reports/2014/barriers2014.pdf>.

By Comparison in Hong Kong the minimum capital requirement for a bank, irrespective of its loan book size and consumer number is HK\$300 million. See HKMA “Licencing Requirements for banks" page 21 available at <http://www.hkma.gov.hk/media/eng/publication-and-research/backgroundbriefs/bank_sup/licensing requirements_for_banks.pdf $>$ 
In either case, the shift by regulators to a forward-looking, from a retrospective, approach is to be welcomed as it should allow markets to become more efficient and competitive, ultimately yielding benefits for consumers and the economy. While different approaches are being employed, this raises the potential for common international approaches to FinTech regulation, to maximize market opportunity while at the same time setting best practices for managing risks to financial stability and consumer protection, similar to those that have been applied in the context of payment systems and other forms of regulation by the international standard setters. ${ }^{149}$ Such a common approach, if implemented, could open the stage for a new era in FinTech. However, just as the issue of when to regulate new technology can be as important as how to regulate it, in our view, the time has not yet come to move to internationally standardized regulatory approaches in this sector. More experimentation and innovation is needed in regulatory approaches and in RegTech, before the time will be ripe to seek their standardization.

\footnotetext{
${ }^{149}$ Such as the Financial Stability Board, Basel Committee on Banking Supervision and International Organization of Securities Commissioners.
} 